\title{
The Effect of Private Fund Expansion on Financial Stability
}

\author{
Junesuh Yi ${ }^{*}$, Professor, Dongguk University
}

\begin{abstract}
$\langle$ Abstract $\rangle$
This study examines the effect of the expansion of the private fund market on financial stability. Specifically, it analyzes the effect of private fund growth on financial markets' as well as financial institutions' returns and on financial stability indicators. Overall, the expansion of the private fund market is found to have a negative effect on the financial market, which varies depending on the fund type. The increase in private fund deteriorates the returns on the stock and alternative investment markets. In addition, the growth of private funds is observed to have a negative effect on financial stability. The expansion ratio in private funds is positively correlated with the Financial Stability Index (FSI) and joint probability of default (JPoD), and has a statistically significant effect on the JPoD growth rate. By fund type, the increase in real estate and special asset funds amplify the increase in FSI growth rate, whereas the increase in bond funds lead to a decrease in all financial stability indicators, helping to maintain financial stability. Consequently, the result raises policy implications that it is necessary to apply a separate management method for each type of private fund.
\end{abstract}

Keywords: Private Fund; Financial Stability; Systemic Risk; JPoD; Financial Stability Indicator

JEL Classification: G23, G24, G32

* Corresponding Author. Address: Dongguk Business School, Dongguk University, 1Gil 30, Pilding-ro, Jung-gu, Seoul, Korea 04682; E-mail: jsyieee@gmail.com; Tel: +82-2-2260-8589; Fax: +82-2-2260-3684.

Received: July 23, 2020; Revised: October 25, 2020; Accepted: November 2, 2020 


\title{
사모펀드 성장이 금융안정에 미치는 영향
}

\author{
이 준 서 (동국대학교 교수)*
}

\begin{abstract}
본 연구는 사모펀드 시장 확대가 금융안정성에 미치는 영향을 분석했다. 구체적으로 사모펀드 성장이 금융시장과 금융기관의 수익률에 미치는 영향을 살펴보고 금융안정지표와의 관련성을 검증하였다. 분석결과 사모펀드 시장 확대는 펀드 유형에 따라 상이하지만 전반적으로 금융시장에 부정적인 영향을 미치는 것으로 밝혀졌다. 사모펀드 증가는 주식시장과 대체투자시장의 수익률을 악화시키는 것으로 나타났다. 또한 8개월의 시차를 두고 부동산가격 상승도 견인하는 것으로 드러났다. 다만 채권형의 경우에는 오히려 시장안정에 공헌하는 것으로 나타났다. 또한 사모펀드 수탁고 증가와 금융기관 수익률간의 관련성에서는 펀드 시장 확대가 금융기관 수익률에 대해 인과관계를 갖기보다 그 반대의 경우, 즉 금융기관 수익률이 펀드 시장 확대에 인과관계를 보이는 경우가 더 많았다. 무엇보다도 사모펀드 증대는 제한적이지만 금융안정성에 부정적인 영향을 미치는 것으로 드러났다. 사모펀드 증가율은 Financial Stability Index(FSI)나 Joint Probability of Default(JPoD), FSI 증가율, JPoD 증가율과 정관계를 보였고 특히 $\mathrm{JPOD}$ 증가에 통계적으로 유의하게 영향을 미치는 것으로 밝혀졌다. 유형별로는 부동산형과 특별자산형 증가가 FSI 증가율을 확대시키는 것으로 밝혀졌다. 반면 채권형의 증가는 모든 금융안정성 지표의 하락을 이끌어 금융안정성 유지에 도움이 되는 것으로 나타났다. 따라서 본 연구결과는 사모펀드 유형별로 별도의 관리방식을 적용할 필요가 있다는 정책적 시사점을 제시한다.
\end{abstract}

핵심 단어 : 사모펀드, 금융안정성, 금융시장, 금융기관, 시스템적 리스크

JEL 분류기호: G23, G24, G32

* 연락담당 저자. 주소: 서울특별시 중구 필동로1길 30 동국대학교 경영 대학, 04682; E-mail: jsyieee@gmail.com; Tel: 02-2260-8589; Fax: 02-2260-3684. 


\section{1. 서론}

사모펀드 시장이 롤러코스터 양상을 보이고 있다. 사모펀드 시장규모는 2016년 공모펀드 시장규모를 추월한 이후 지속적인 성장세를 거듭, 2019년 말 기준 순자산(NAV) 416조 원으로 242조 원의 공모펀드를 크게 앞서가고 있다. 하지만 2019년 하반기부터 사모펀드 관련 각종 사건사고가 발생하면서 순자산이 감소하는 등 성장세가 주춤하고 있다. 그럼에도 순자산 200조 원 대에서 횡보세를 지속하고 있는 공모펀드와 비교할 때 사모펀드 시장의 약진은 주목할 만하다.

금융당국은 그동안 사모펀드의 규제완화책을 지속적으로 추진해왔다. 2011년 한국형 헤지펀드 도입과 2015년 사모펀드 제도개편을 통해 사모펀드를 전문투자형과 경영참여형으로 구분하여 체제를 정비하고 투자자 조건이나 자산운용사 설립 요건을 대폭 완화했다. 전문사모 운용사에 대해 인가제에서 등록제로 완화하고 자기자본 요건도 40 억 원에서 20 억 원, 10 억 원으로 하향 조정했으며 투자자의 최소투자금액도 5 억 원에서 1 억 원으로 완화했다. 이에 따라 전문투자형으로 분류되는 헤지펀드의 경우 2019년 말 순자산 35조 원, 펀드 수 3,057개를 기록, 단기간에 엄청나게 빠른 속도로 성장했다. 또한 경영참여형으로 구분되는 $\mathrm{PEF}$ (Privave Equity Fund)의 경우도 급성장하면서 약정액 84조 원, 이행액 62조 원, $\mathrm{PEF}$ 수 721 개를 기록했다. 더구나 부동산 가격 상승과 대체투자에 대한 관심이 높아지면서 부동산펀드와 특별자산펀드의 수탁고가 크게 증가하며 사모펀드 시장 확대를 견인하고 있다.

하지만 2019년 말 DLF(Derivatives Linked Fund) 사태와 라임자산운용 사태1)가 발생하면서 사모펀드에 대한 부정적인 시각이 확산, 성장세는 둔화되고 있다. 금융당국도 고위험투자자 보호책과 사모펀드 제도개편을 잇달아 발표하면서 사모펀드 규제완화에 대해 속도를 조절하고 있는 것으로 보인다.2)

이 같은 사모펀드 시장의 단기적 확대는 금융시장 안정에 위협요인으로 작용할 수도 있을 것이라는 우려의 목소리가 제기된다. 사모펀드는 레버리지나 파생상품 활용이 비교적 자유롭고 투자유형에 따라 펀드간 쏠림(herding)현상이 두드러지게 나타나며, 대형 금융기관이 프라임 브로커 역할을 수행함에 따라 사모펀드 시장에 예상치 못한 충격이 발생하는 경우 금융시스템 전반에 걸쳐 부정적인 영향을 미칠 수도 있기 때문이다. 1998년에는 헤지펀드인 롱텀캐피털 매니지먼트(LTCM)의 파산으로 국제금융시장이 일대 혼란을 겪었고 2008 년 금융위기 시기에도 헤지펀드가 시장위험 전염의 주 창구역할을 했다는 주장은 이를 뒷받침한다.

1) DLF 사태란 독일금리 DLS에 투자한 DLF가 독일금리의 마이너스 진입으로 원금 손실이 발생하였고 해당 DLF 판매과정에서 은행의 불완전 판매 사실이 드러난 사건이다. 라임사태란 라임자산운용이 $\mathrm{CB}, \mathrm{BW}$ 등 메자닌펀드로 운용하던 투자자산이 부실화되면서 발생한 대규모 환매 중단 사태로 라임자산운용의 불법자전거래나 수익률 조작 의혹이 불거진 사건이다.

2) 금융당국은 2019년 11월 고난도 금융투자상품 도입, 사모펀드의 일반투자자 요건 강화, OEM펀드 판매사 책임 강화, 은행의 고위험상품 판매 제한 등 고위험 금융상품에 대한 투자자 보호 강화책을 마련하였다. 또한 2020년 4월에는 수탁기관과 프라임브로커의 관리감독 강화, 일반투자자에 대한 상품 설명의무 강화, TRS 차입운용 펀드에 대한 투자자 보호장치 마련, 금융당국의 감독검사 강화 등을 포함하는 사모펀드 제도 정비안을 발표했다. 
The Effect of Private Fund Expansion on Financial Stability

사모펀드는 일단 운용자의 대리인 문제가 상당한 수준으로 발생할 수 있는 구조이다. 사모펀드 유형에 따라 조금씩 다르지만 대부분의 사모펀드는 운용보수 이외에 성과보수를 부과한다. 그런데 성과보수를 받기 위해서는 사전에 설정한 수익률을 초과 달성해야만 한다. 따라서 운용자는 이를 위해 레버리지를 활용한 과다투자나 고위험 자산에 대한 투자, 특정 자산에 대한 투자 쏠림현상 등을 일으킨다. 이는 곧 시장의 유동성 감소와 변동성 증대로 이어져 시장의 안정성을 저해시킬 수 있다. 또한 투자은행이나 증권사들은 프라임 브로커로서 증권대차나 레버리지 제공, 공매 등 신용제공, 복잡한 파생상품의 거래 상대방 역할 등을 수행하면서 금융시장 위험전염의 매개 역할을 할 수도 있다. 이와 함께 사모펀드는 대체투자의 일환으로 최근 투자대상의 다변화를 실시하면서 부동산이나 인프라, 파생상품으로의 투자비율을 증대, 만일 사모펀드가 부실화되는 경우 금융시장 뿐 아니라 실물시장에도 악영향을 미칠 수 있는 것이다.3)

이에 따라 본 연구에서는 사모펀드 시장의 급격한 확대가 금융시장 안정성을 저해시키는가를 분석하고자 한다. 물론 최근의 사모펀드 관련 사건 사고는 시장규율이 제대로 지켜지지 않아 발생한 운용사나 판매사의 일탈행위로 보는 시각도 있지만 본 연구를 통해 사모펀드와 금융안정성 간의 보다 근본적인 관계를 모색하고자 한다. 이를 위해 우선 사모펀드의 자금유출입이 시장리스크 측면에서 금융시장 및 금융기관의 수익률에 미치는 영향을 분석한다. 또한 사모펀드 시장 규모 확대가 시스템적 리스크(systemic risk)로 대변되는 거시건전성에 미치는 영향도 분석한다. 이와 함께 사모펀드로의 자금유출입과 관련된 금융업종간 상호연계성(interconnectedness) 및 사모펀드 시장의 구조적변화 시점을 파악하여 변화시점 이후의 사모펀드 시장이 시장건전성에 미치는 영향도 살펴본다.

사실 사모펀드와 파생상품은 글로벌 금융위기 이후 위기발생의 주범으로 지목된 바 있다. 이에 따라 주요국 금융당국들은 금융시장의 시스템적 리스크를 효과적으로 관리하기 위해 이들에 대한 감독과 규제를 강화하였다. 미국은 도드-프랭크법(Dodd-Frank Act)을 통해 운용규모 1 억 달러 이상의 헤지펀드와 1.5 억 달러 이상의 사모펀드에 대해 증권거래위원회(SEC)에 투자자문사로 등록하게 하고 운용자산 규모나 레버리지, 거래 상대방 리스크, 자산포트폴리오, 가치평가 방식 등을 주기적으로 보고하도록 했다. 물론 최근에는 도드-프랭크법을 완화하는 방향으로 규제책이 다소 약화되기는 했지만 아직도 시스템적 리스크를 발생시킬 만한 사항에 대해서는 규제책을 유지하고 있다. 또한 금융안정위원회(FSB)와 국제증권감독기구(IOSCO)도 은행업 및 보험업과 마찬가지로 대형 펀드 또는 대형 자산운용사에 대한 규모, 상호연계성, 대체가능성, 복잡성 등을 기준으로 시스템적으로 중요한 금융회사(SIFIs)로 지정하는 방안을 논의하기도 하였다.

하지만 이와 관련된 선행 연구 결과를 보면 사모펀드 시장이 금융안정성을 저해한다는 뚜렷한 증거를 찾기는 쉽지 않다. 오히려 역으로 금융시장의 가격변동 및 경제 환경의 변화가 사모펀드 시장의 자금 유출입에 영향을 미치는 것으로 조사되고 있다. 예컨대 $\mathrm{ECB}(2008)$ 는 헤지펀드의 자금유출입이 펀드의 전기수익률, 전기자금유출입, 투자자의 위험회피 태도변화, 단기시장금리의 변동에 의해 영향을 받는 반면 시장리스크에는 영향을 주지 않는다는 사실을 밝혀냈다. 즉

3) 대체투자 관점에서의 사모펀드 투자는 $\mathrm{Yi}(2017 \mathrm{a})$ 참조하라. 
한국증권학회지 제49권 6호 (2020)

헤지펀드의 자금유출입이 자본시장의 급격한 가격 변동 및 유동성 위험을 가져와 시스템적 리스크에 영향을 미친다기 보다 반대로 시장의 변화에 따라 투자자들이 헤지펀드에 대한 자금유출입을 도모한다고 주장했다. 또한 Billio et al.(2012)도 은행, 증권, 보험, 헤지펀드의 수익률에 대한 상호연계성과 시스템적 리스크에 미치는 영향을 조사한 결과 은행이 다른 금융기관에 비해 시장 충격을 전달하는 가장 중대한 역할을 수행함을 보였다. $\operatorname{IMF}(2015)$ 도 자산운용업과 금융안정성간의 관계를 주제로 한 보고서에서 사모펀드보다 훨씬 시장 규모가 큰 공모펀드도 시스템적 리스크를 유발한다고 보기는 어렵다고 밝혔다. 다만 유동성이 낮은 시장에서는 펀드가 자산 가격에 동적으로 영향을 미칠 수는 있다고 설명했다. Chan et al.(2006)은 헤지펀드 자체가 아닌 헤지펀드 수익률과 다른 자산 수익률간의 상관관계 하락으로 인한 투자수익률 감소가 시스템적 리스크 발생 원인이 될 수 있다고 지적했다.

더구나 국내 사모펀드의 경우 대부분 연기금 등 기관투자자들의 위탁자금이 대부분으로 투자대상이나 투자종목 투자범위가 이미 지정되어 있다. 따라서 운용사들의 투자자율성은 비교적 낮은 편으로 급격한 변동성을 초래할 가능성은 높지 않다. 또한 채권형이 84조 원으로 사모펀드 전체 순자산의 $20.2 \%$ 를 차지하고 있어 비교적 안정적으로 운용되고 있다고 볼 수 있다. 특히 이들 채권형은 대부분 연기금 등 기관투자자들의 투자자금으로 경제지표 변동에 따른 환매 가능성이 낮아 사모펀드의 안정성 유지에 기반 역할을 수행하고 있는 것으로 추론할 수 있다.

그러나 지난해 하반기부터 시작된 사모펀드의 사건사고로 인해 사모펀드 운용에 대한 신뢰도가 급전직하하면서 사모펀드도 금융안정성을 저해시킬 수 있는 잠재군일 수 있음을 시사했다. 메자닌펀드 운용을 위한 과도한 전환사채 발행, ELF 및 DLF 헤지를 위한 과도한 외환활용, 신뢰성 저하로 인한 대량 환매요구 등 사모펀드로 인한 위해요인이 증가하고 있다. 더구나 헤지펀드들은 레포(Repo) 매도를 통한 레버리지 투자를 확대해 RP시장을 극단적인 익일물 시장으로 왜곡시키는 주체역할도 하고 있는 것으로 알려지고 있다. 즉 헤지펀드들이 프라임 브로커를 거치지 않고 회사채를 매입한 후 채권대차시장에서 국채와 같은 우량 채권으로 교환한 후, 레포 시장에서 이를 담보로 자금을 조달하고 있다(Baek, 2018). 무엇보다도 최근 부동산이나 인프라 등 특별자산형의 급증도 경제지표 변화 시 사모펀드의 위험성을 증대시킬 수 있는 요인으로 볼 수 있다. 물론 부동산형이나 특별자산형의 경우 해외부문이 상당수를 차지하고 있지만 지난해 처음으로 채권형을 앞서며 가장 규모가 큰 사모펀드 유형으로 자리잡고 있다. 부동산 시장 침체나 사회간접자본(SOC)에 대한 투자 감소 시 실물 경제 부진이 금융시장의 시스템적 리스크 증대로 이어질 가능성이 있는 이유이다.

본 연구에서는 이에 따라 사모펀드가 금융시장 안정화에 미치는 영향에 대한 분석을 통해 사모펀드로 인해 발생하는 위험을 최소화할 수 있는 방안을 모색하고자 한다. 본 연구는 이를 위해 다음과 같은 네 가지의 분석을 실시한다. 먼저 사모펀드 시장 성장이 금융시장의 안정성에 미치는 영향을 시장리스크 측면에서 살펴본다. 즉 사모펀드 시장규모와 주식, 채권, 파생, 부동산, 대체투자시장의 지수 수익률 간의 인과관계 및 영향정도를 파악한다. 사모펀드 전체 증가율과 함께 펀드유형별 쏠림현상의 분석을 위해 사모펀드를 주식형, 채권형, 혼합주식형, 혼합채권형, 파생형, 부동산형, 특별자산형 등으로 구분하여 분석을 실시한다. 
The Effect of Private Fund Expansion on Financial Stability

두 번째로 사모펀드 시장 성장이 금융기관의 안정성에 미치는 영향을 분석한다. 금융업종을 금융업 전체, 은행, 보험, 증권, 기타금융으로 구분하여 이들의 업종 평균 주가수익률과 사모펀드 시장 규모의 관련성을 분석한다. Garbaravicius and Dierick(2005)도 사모펀드가 금융시스템에 부정적인 영향을 미친다면 그것은 금융시장이나 금융기관을 통해 현실화될 것이라고 주장한 바 있다.

셋째로 사모펀드 시장 성장이 거시건전성에 미치는 영향을 분석한다. 즉 시스템적 리스크의 조기경보 지표로서 활용되고 있는 FSI(Financial Stability Index)와 JPoD(Joint Probability of Default)를 거시건전성을 대표하는 지표로 활용하여 이들 지표와 사모펀드 시장 규모간의 연관성을 살펴본다. 거시건전성의 경우 수준보다 증분지표가 보다 유의한 의미를 가질 수 있으므로 $\mathrm{FSI}$ 와 $\mathrm{JPoD}$ 의 증가분에 대한 분석도 함께 실시한다.

마지막으로 펀드로의 자금유출입과 관련된 금융업종간의 상호연계성을 살펴본다. 즉 자금 순환표 상 펀드로 유출된 자금에 대한 금융업종간 연계성 검증(사모펀드 입장에서는 금융업종별 자금원천)을 실시한다. 금융업종은 일반은행, 특수은행, 신탁, 서민금융기관, 보험, 증권, 여신전문 기관 등으로 구분한다. 다만 한국은행 자금순환표 상에는 공모와 사모를 모두 포함하는 투자펀드 로만 구분이 되어 있어 사모펀드 자금유출입과 관련된 금융업종간의 상호연계성을 정확하게 파악하기 어려운 실정이다.

본 연구의 구성은 다음과 같다. 제 2장에서는 사모펀드 시장 및 금융안정 현황을 살펴보고 제 3장에서는 자료 및 방법론에 대해 기술한다. 제 4 장에서는 여러 가지 실증분석에 대한 결과를 기술하며 제 5 장에서는 요약 및 정책적 시사점을 제시한다.

\section{2. 사모펀드 및 금융안정 현황}

\section{1 사모펀드 현황}

채권형 중심의 일반사모펀드 위주로 운용되던 사모펀드는 2004년 PEF, 2011년 헤지 펀드를 도입하면서 다양한 유형의 시장으로 발전하였다. 이후 2015년 사모펀드 활성화를 위해 자본시장법을 개정하면서 체제 정비와 규제완화를 시행하였다. 그 결과 <그림 $1>$ 과 같이 사모펀드 시장은 급성장하면서 공모펀드 시장규모를 초과한 이후 그 차이는 점차 더 확대되고 있다.

사실 자본시장법 개정 이전의 사모펀드는 연기금을 포함한 기관투자가 위주의 채권형 단독펀드가 주를 이루었다. 기관투자가 위주의 단독펀드의 경우, 형식은 사모펀드이지만 안정적 수익 창출이 목적인만큼 공모펀드와 유사한 수준의 운용규제가 존재하였다. 이 같은 유형의 일반사모펀드는 법 개정이후 전문투자형 사모펀드로 편입되었다. 전문투자형은 기존의 일반사모펀드에 비해 프라임 브로커 서비스나 레버리지를 활용할 수 있고 운용규제도 낮아 진정한 의미의 사모펀드로 간주되고 있다. 이에 따라 최근에는 기관투자자뿐 아니라 고액자산가 $(\mathrm{HNWI})$ 를 중심으로 개인투자가들도 사모펀드 시장에 가세하면서 시장의 외형이 확대되고 있는 것이다. 
〈그림 1〉사모펀드와 공모펀드의 연도별 순자산(NAV)총액 추이

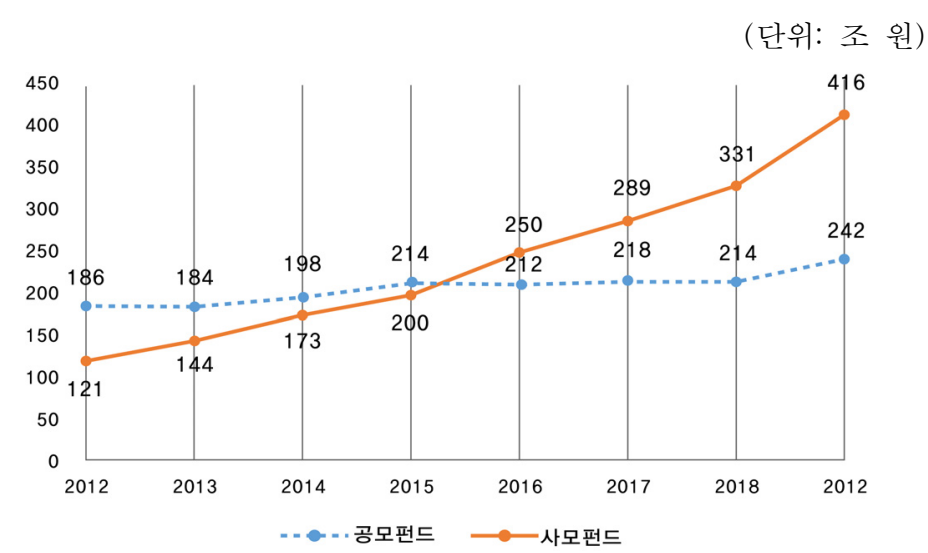

출처: 금융투자협회.

투자유형별로는 <표 $1>$ 과 같이 부동산형이 97 조 원으로 가장 큰 비중을 차지하고 있으며 특별자산 90 조 원, 채권형 84조 원을 기록하고 있다.4) 특히 부동산 가격의 상승으로 부동산형은 지속적인 증가세를 보이고 있으며 인프라나 무형자산 등 대체자산에 주로 투자하는 특별자산형도 꾸준한 증가세를 보이고 있다. 이들 실물펀드의 수탁고는 지난 3년간 2 배가량 증가하였다. 또한 유동성공급 확대로 인한 대기성 자금 유입으로 $\mathrm{MMF}$ 의 단기금융형 순자산이 빠르게 증가하고 있으며 파생상품에 투자하는 파생형의 증가세도 눈에 띈다. 이 밖에 헤지펀드 중 투자유형이 기존 분류기준에 해당하지 않는 혼합자산형도 증가세가 가파르다.

〈표 1〉 투자유형별 사모펀드 연도별 순자산(NAV)총액 추이

(단위: 억 원)

\begin{tabular}{lrrrrrrr}
\hline & \multicolumn{1}{c}{2013} & \multicolumn{1}{c}{2014} & \multicolumn{1}{c}{2015} & \multicolumn{1}{c}{2016} & \multicolumn{1}{c}{2017} & \multicolumn{1}{c}{2018} & \multicolumn{1}{c}{2019} \\
\hline 주식 & 78,922 & 98,633 & 115,547 & 113,726 & 143,297 & 153,569 & 153,058 \\
혼합주식 & 39,733 & 42,717 & 31,741 & 34,629 & 36,968 & 40,125 & 45,003 \\
혼합채권 & 152,751 & 169,109 & 120,878 & 97,853 & 71,064 & 61,209 & 50,771 \\
채권 & 436,929 & 565,555 & 668,639 & 800,690 & 725,777 & 757,777 & 840,191 \\
재간접 & 43,816 & 61,556 & 64,949 & 101,136 & 139,768 & 155,125 & 222,298 \\
단기금융 & 28,649 & 39,830 & 80,005 & 178,411 & 253,551 & 202,249 & 315,369 \\
파생형 & 194,625 & 190,745 & 179,492 & 227,017 & 271,972 & 285,556 & 304,880 \\
부동산 & 231,551 & 286,158 & 350,408 & 458,883 & 593,785 & 747,835 & 974,100 \\
특별자산 & 233,364 & 278,152 & 364,554 & 440,682 & 538,017 & 675,630 & 900,249 \\
혼합자산 & - & - & 21,773 & 48,735 & 118,932 & 227,319 & 358,573 \\
\hline 합계 & $1,440,340$ & $1,732,456$ & $1,997,984$ & $2,501,762$ & $2,893,130$ & $3,306,444$ & $4,164,583$ \\
\hline
\end{tabular}

출처: 금융투자협회.

4) 유형에 대한 분류기준은 펀드평가기관, 자산운용기관에 따라 상이할 수 있다. 본 연구에서는 금융투자 협회의 사모펀드 분류기준을 따른다. 
The Effect of Private Fund Expansion on Financial Stability

2019년 말 기준 사모펀드 순자산총액 중 406.6조 원(97.7\%)이 투자신탁형태로 운용되고 있으며 258.4조 원(62.0\%)이 국내에 투자되고 있고 370.4조 원(88.9\%)은 전문사무수탁사가 사무관리회사의 기능을 담당하고 있다. 또한 판매와 관련해서는 336.7 조 원(82.7\%)이 증권사를 통해 판매되었으며 고객유형별로는 금융기관이 297 조 원(72.9\%)으로 절대다수를 차지하고 있다.

금융당국은 최근 적격일반투자자의 최저투자금액을 1 억 원에서 3 억 원으로 상향조정하는 한편 설명의무나 운용보고서 발급을 의무화하는 등 투자자보호책을 강화하였다. 또한 사무수탁사 및 프라임브로커의 펀드에 대한 감시기능과 판매사에 대한 책임을 강화하고 시장규율을 정비하여 위험관리를 강화하기도 하였다. 이 같은 제도개편으로 사모펀드 시장의 성장세는 한 풀 ㄲㄲㄲ였으나 최근 양적완화에 따른 유동성 증가로 향후 사모펀드 시장의 성장잠재력은 여전히 존재하고 있다고 볼 수 있다.

\section{2 금융안정 현황}

금융안정이란 금융회사들이 정상적인 자금중개기능을 수행하고 금융시장 참가자들의 신뢰가 유지되는 가운데 금융인프라가 잘 구비되어 있어 금융시스템이 원활히 작동하는 상태를 의미 한다.5) 금융시스템이 안정성을 유지하기 위해서는 거시건전성이 확보되어야 하며 효과적인 거시건전성 정책을 수행하기 위해서는 시스템적 리스크(systemic risk)에 대한 파악이 선결 되어야 한다. 거시건전성정책이 기본적으로 시스템적 리스크를 식별하고 이를 통제하여 금융 불안이 실물경제로 파급되는 것을 방지하기 위한 정책이기 때문이다.

시스템적 리스크를 측정하는 방법은 기대부족액(SES: systemic expected shortfall), 한계기대부족액(MES: marginal expected shortfall), 보험프리미엄(DIP: distress insurance premium), CoVAR 등 상당히 다양하다.6) 한국은행은 금융안정보고서에서 FSI(Financial Stability Index)를 활용해 금융안정지표로 활용하고 있으며 내부적으로는 JPoD(Joint Probability of Default) 지표를 관리하고 있는 것으로 알려져 있다.

$\mathrm{FSI}$ 는 20개 경제관련 지표에 대해 표준화 작업을 실시한 후 가중평균을 통해 금융변동성을 측정하는 지수로 $0 \sim 100$ 범위 내에서 표시된다. $\mathrm{JPOD}$ 는 개별은행의 $\mathrm{CDS}$ 스프레드와 채권 스프레드를 통해 개별은행의 재무곤경확률을 산출하고 이를 근거로 시간 경과에 따른 거시경제 지표의 위험성을 포함하여 도출한 결합재무곤경확률이다.

<그림 2>는 FSI와 $\mathrm{JPOD}$ 의 기간별 변동추이를 보여 주고 있다. 두 지표 모두 2008년 금융위기 시기에 그 이전에 비해 거의 10 배 이상 수치가 증가한 것을 볼 수 있다. 두 지표는 금융위기 이후 안정세를 취하다 2012년 유럽 발 금융위기 시 다시 증가하는 양상을 나타냈지만 그 이후에는 금융안정과 관련된 특이한 상황을 보이지 않고 비교적 안정적인 추세를 시현하고 있다. 2006 년부터 현재까지 $\mathrm{FSI}$ 와 $\mathrm{JPOD}$ 의 월평균 수치는 $9.21,0.35 \%$ 이며 중앙값은 $\mathrm{FSI} 6.25, \mathrm{JPOD}$

5) 한국은행 금융안정보고서(Bank of Korea, 2012) 상의 정의.

6) Bisias et al.(2012)는 시스템적 리스크 측정 방법이 31가지에 이른다고 설명했다. 
한국증권학회지 제49권 6호 (2020)

$0.13 \%$ 이다. <그림 2>에서 보는 바와 같이 FSI가 JPoD에 비해 변동 폭이 커서 위험에 대해 상대적으로 민감한 것으로 나타나고 있다. 또한 $\mathrm{JPOD}$ 에 비해 $\mathrm{FSI}$ 가 위험을 다소 선제적으로 인지하고 위험에 대한 지속성도 장기적으로 나타나고 있는 것으로 분석된다.

〈그림 2〉 FSI와 JPoD의 기간별 변동추이

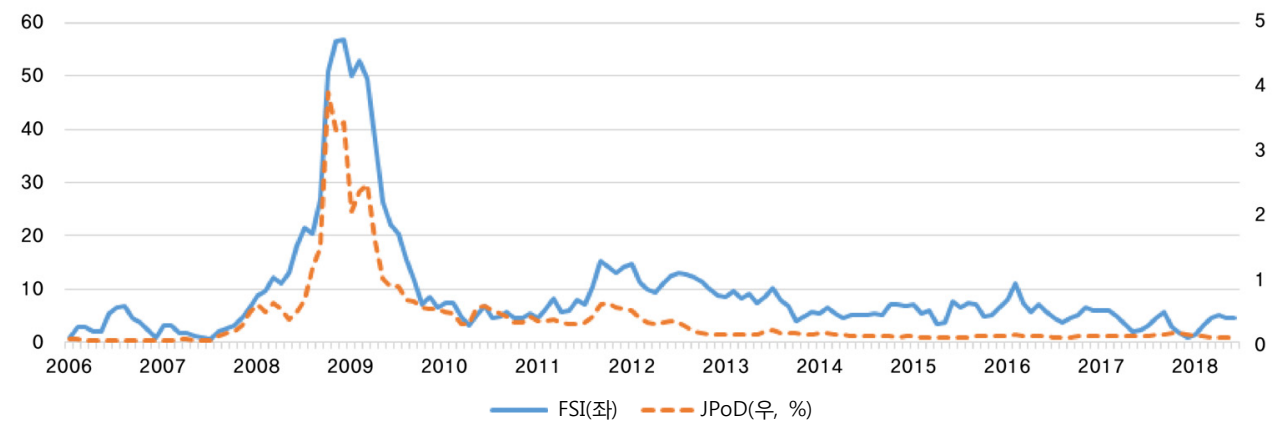

\section{3. 자료 및 방법론}

\section{1 자료}

본 연구의 표본기간은 2006년부터 2018년 6월까지 월단위이다. 단, 금융업종의 투자펀드에 대한 자금유출입 자료는 한국은행에서 제공하는 자금순환표를 활용했으며 기간은 2009년부터 2018년 3월까지로 분기단위이다. 주요변수들은 사모펀드 유형별 증가율, 금융시장별 수익률, 금융업종별 수익률, 그리고 금융안정지표들이다. 사모펀드 증가율은 금융투자협회가 제공하는 종합통계시스템(FreeSIS)을, 금융업종별 수익률은 FnGuide를 각각 활용하였다. FSI와 JPoD등 금융안정지표는 한국은행에서 제공받았으며 금융시장 수익률은 FnGuide, KIS채권평가, 제로인, 한국은행 등에서 제공받았다. 금융업종별 사모펀드에 대한 자금흐름은 한국은행에서 분기별로 발표하는 자금순환표 상 금융업종별 투자펀드로 운용한 자금유출입 자료와 금융투자협회에서 발표하는 공모펀드 및 사모펀드의 월별자금유출입 자료를 혼합해서 추출하였다. 즉 자금순환표 상의 투자펀드는 사모펀드와 공모펀드를 모두 포함하므로 월별자금유출입 자료 상의 공모펀드와 사모펀드 비율을 근거로 자금흐름표 상의 투자펀드를 공모와 사모로 안분 배분하였다. 금융업종은 일반은행, 특수은행, 신탁, 서민금융기관, 보험, 증권, 여신전문기관 등으로 구분하였다.

사모펀드 수탁고 증가율, 금융시장 수익률, 금융업종별 수익률, 금융안정지표의 기초통계량은 <표 2>에 정리되어 있다. 사모펀드 수탁고의 증가율은 주식형, 주식혼합형, 채권형, 채권혼합형, 파생상품형, 부동산형, 특별자산형 등 7개 유형과 증권형,7) 펀드 전체 등 9 개 유형으로 구분하여 산출했다. 표본기간 중 전체 사모펀드는 월 $0.94 \%$ 가 증가했으며 특별자산형, 부동산형, 파생상품형 순으로 증가율이 높았다. 반면 주식혼합형과 채권혼합형은 월 평균 수탁고가 감소하는 것으로

7) 주식형, 주식혼합형, 채권형, 채권혼합형의 합. 
The Effect of Private Fund Expansion on Financial Stability

나타났다. 증가율 분포와 관련해 한 가지 흥미로운 사실은 주식과 채권 등 전통적 유형의 펀드들은 왼쪽으로 긴 꼬리를 갖는(skewed to the left)반면 특별자산이나 부동산형 등 최근에 급부상하고 있는 유형의 펀드들은 오른쪽으로 긴 꼬리를(skewed to the right) 보인다는 점이다. 또한 첨도도 최근 유형 펀드들이 전통 유형 펀드들에 비해 높게 나와 월 수익률의 극단치가 많음을 보여주고 있다.

〈표 2〉변수 기초통계량

\begin{tabular}{|c|c|c|c|c|c|c|c|c|}
\hline & & 평균 & 중위값 & 최대 & 최소 & 표준편차 & 왜도 & 첨도 \\
\hline \multirow{9}{*}{$\begin{array}{l}\text { 펀드 } \\
\text { 유형 별 } \\
\text { 증가율 }\end{array}$} & 사모펀드총 $(\mathrm{F} 1)^{\dagger}$ & 0.0094 & 0.0110 & 0.1118 & -0.0720 & 0.0242 & -0.0819 & 6.3823 \\
\hline & & 36 & 0.0065 & 1052 & -0.1029 & 0279 & & 3538 \\
\hline & & 0.0064 & 0.0085 & 1691 & -0.1628 & 0.0469 & -0.1378 & 5.0171 \\
\hline & 주소 & -0.0005 & 0.0072 & 0.2469 & -0.2922 & 0587 & -0.9534 & 9.5638 \\
\hline & 채권 & 052 & 0.0077 & 1240 & -0.1103 & 367 & -0 . & 4.5636 \\
\hline & 채군 & -0.0068 & -0.0063 & 0.0771 & -0.1837 & 0.0393 & -0.8454 & 5.7585 \\
\hline & & 0.0120 & 0.0102 & 0.3138 & -0.2374 & 0.0500 & 0.5717 & 14.6032 \\
\hline & & 0.0280 & 0.0177 & 0.2134 & -0.0151 & 0.0338 & 2.6425 & 11.9624 \\
\hline & 특별 & 0.0318 & 0.0178 & 0.3078 & -0.0494 & 0.0485 & 3.6748 & 19.5152 \\
\hline \multirow{9}{*}{$\begin{array}{l}\text { 시장별 } \\
\text { 수익률 }\end{array}$} & KOS & 046 & 0.0064 & 1352 & -0.2313 & 0490 & -0.6929 & 6.5336 \\
\hline & KIS & & 37 & 29 & -0.0152 & 55 & 82 & .5833 \\
\hline & 스프 & & 0 & 00 & -0.4500 & 020 & 4.4380 & 29.7510 \\
\hline & 국채 3 & 0.0005 & 0.0013 & 0.0344 & -0.0245 & 0.0078 & 0.3005 & 5.7237 \\
\hline & 주식 & 0.0042 & 0.0047 & 0.0715 & -0.1130 & 0.0250 & -0.6548 & 6.0627 \\
\hline & 채권 & 0.0040 & 0.00 & 0.0406 & -0.0539 & 0.0136 & -0.4 & 5.0568 \\
\hline & 코스 & 0.004 & 0.0042 & 0.1501 & -0.2095 & 0.0530 & -0.3858 & 4.7898 \\
\hline & 아표 & 0.00 & 0.0047 & 0.0474 & -0.0621 & 0.0146 & -0.8768 & 8.1016 \\
\hline & 대체 & 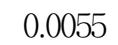 & 0.0064 & 0.0840 & -0.1355 & 0.0294 & -0.6640 & 6.4829 \\
\hline \multirow{5}{*}{$\begin{array}{l}\text { 금융 } \\
\text { 업종별 } \\
\text { 수익률 }\end{array}$} & 금융업종 전체(R & 0.0013 & 0.0012 & 2156 & -0.3157 & 628 & -0.5284 & 7.6802 \\
\hline & 은힝 & & -0.0 & 1 & -0 . & 791 & -0 & 5.8748 \\
\hline & 증권 & & -0.0 & 9 & -0.2978 & 949 & & 3.3094 \\
\hline & 보험 & 00 & -0.0001 & 0.3088 & -0.2869 & 0.0647 & -0.2112 & 9.0971 \\
\hline & 기타 & 0017 & 0.0032 & 0.1866 & -0.2904 & 0.0814 & -0.3081 & 4.1881 \\
\hline \multirow{4}{*}{$\begin{array}{l}\text { 금융안정 } \\
\text { 지표 }\end{array}$} & FSI지 & 21 & 0.0625 & 0.5679 & 0.0073 & 0.1045 & 3.1852 & 13.3906 \\
\hline & 율(S2) & 15 & 0.0014 & 2.9392 & -0.6457 & 0.4799 & 3.3613 & 18.9550 \\
\hline & Jpod & 37 & 0.1263 & 3.9168 & 0.0256 & 0.6054 & 3.8607 & 19.2667 \\
\hline & Jpod 증가율 $(\mathrm{S} 4)$ & 0.0302 & -0.0095 & 1.6630 & -0.4067 & 0.2842 & 2.9929 & 16.4137 \\
\hline
\end{tabular}

주) ${ }^{1} \mathrm{KOSPI} 50 \%+\mathrm{KIS}$ 채권종합 $50 \%$

${ }^{2} \mathrm{KOSPI} 25 \%+\mathrm{KIS}$ 채권종합 $75 \%$

${ }^{3}(\mathrm{KOSPI}+0.2 \%) \times 0.6+(\mathrm{Kis}$ 채권종합 $+0.1 \%) \times 0.4$

4 original FSI지수 $\times 0.01 \mathrm{OSPI} 50 \%+\mathrm{KIS}$ 채권종합 50\%

${ }^{5}$ original $\mathrm{JPoD} \times 100$

† 사모펀드 유형별 증가율: $\mathrm{F} 1 \sim \mathrm{F} 9$, 금융시장별 수익률: $\mathrm{I} 1 \sim \mathrm{I}$, 금융업종별 수익률: $\mathrm{R} 1 \sim \mathrm{R} 5$, 금융안정지표: $\mathrm{S} 1 \sim \mathrm{S} 4$. 
한국증권학회지 제49권 6호 (2020)

각 금융시장의 수익률은 주식, 채권, 파생, 부동산, 대체투자 시장의 시장지수를 통해 산출하였다. 주식시장 수익률은 KOSPI 지수를 활용하였다.8) 채권시장 수익률은 실제로 시장에서 거래되는 비율만큼 채권유형과 만기에 대해 가중치를 부여해 지수화 한 KIS종합채권지수와 스프레드 (BBB-국채 3년물), 그리고 국채 3년물 수익률을 사용하였다. 주식혼합과 채권혼합 시장 수익률은 각각 KOSPI 50\%+KIS종합 50\%와 KOSPI 75\%+KIS종합 25\%으로 계산하였다. 파생상품시장 수익률은 KOSPI200 선물을 활용하였으며 부동산 시장 수익률은 관련 지표 중 민감도가 가장 높은 서울 아파트 매매지수를 활용하였다. 대체투자 시장 수익률은 제로인에서 대체투자 벤치마크 $(\mathrm{BM})$ 로 활용하는 $(\mathrm{KOSPI}+0.2 \%) \times 0.6+(\mathrm{KIS}$ 종합 $+0.1 \%) \times 0.4$ 의 산식을 원용하였다. 시장별 수익률에서는 대체투자시장 수익률이 월 $0.55 \%$ 로 가장 높았다.

금융업종별 수익률은 은행, 증권, 보험, 기타금융과 금융업종 전체로 구분하여 파악했다. 이 중 은행, 증권, 보험은 코스피 금융업종 지수(가중평균)중 해당 금융업종의 지수를 활용했으며 기타금융은 FnGuide Industry Group상 기타금융으로 분류되는 금융기관의 수익률을 지수화 하였다. 월평균 수익률은 보험업종이 가장 높았으며 이어서 은행, 증권 순서였다. 하지만 중위 수익률은 기타금융을 제외한 전 금융업종에서 마이너스를 기록했다.

\section{2 방법론}

본 연구에서 활용한 금융시장 안정성 지표는 $\mathrm{FSI}$ 와 $\mathrm{JPoD}$ 이다. FSI는 세 단계의 과정을 거쳐 산출된다. 먼저 은행(연체율 등), 주식·외환·채권시장(주가 및 환율 변동성, 금리스프레드 등), 대외거래 및 대외지급(경상수지, $\mathrm{CDS}$ 프리미엄 등), 실물경제(성장률, 물가상승률 등), 가계 및 기업의 경제상황(소비자동향지수, 기업경기지수 등)의 금융안정과 속보성을 나타내는 20 개 지표를 선정한다. 다음으로 선정된 지표를 비교 평가할 수 있게 각 지표에 대해 Z값을 산출하는 표준화 작업을 시행한다. 마지막으로 각 지표에 대해 가중평균을 실시한다. 가중평균은 다음 식 (1)과 같이 측정값의 표준편차 역수로 가중평균하는 등분산가중평균 방법을 활용한다.

$$
\text { 가중평균값 }=\sum\left(\text { 측정값 } \times w_{i}\right) \text {, 단 } w_{i}=\left(\frac{1}{S D_{i}}\right) / \Sigma\left(\frac{1}{S D_{i}}\right)
$$

가중평균된 각 지표의 값은 (측정값-시계열상의 최소값)/(시계열상의 최대값-시계열상의 최소값)의 상대적 크기비교 방식을 통해 0부터 100사이의 FSI 값을 갖게된다.9)

두 번째 금융안정지표인 $\mathrm{JPOD}$ (결합부도확률)는 금융시스템의 꼬리위험(tail risk)을 측정하는 것으로 모든 금융기관들이 시스템적으로 파산하게 될 확률을 의미한다. 본 측정방법은 금융 시스템을 개별 금융기관들의 포트폴리오로 간주하여 시스템적 리스크를 개별 금융기관과 금융기관 간 자산가치의 변화를 특징짓는 금융시스템 다변량밀도 함수(BSMD)를 통해 산출한다. 즉

8) 주식시장 수익률을 대표하는 것은 코스피와 코스닥을 모두 포함하는 KRX지수이지만 KRX지수가 본 연구의 표본기간 시작시점 이후에 출시됨에 따라 활용 불가능하였다.

9) FSI 산출방법에 대한 보다 자세한 내용은 Bank of Korea(2012) 한국은행 참조. 
The Effect of Private Fund Expansion on Financial Stability

$\mathrm{BSMD}$ 는 금융기관 간의 재무곤경에 대한 선형, 비선형적 의존성을 포함시킨다. $\mathrm{JPoD}$ 도 세 단계의 과정을 거쳐 산출된다. 먼저 개별 금융기관의 재무곤경 확률을 계산하고 이를 근거로 $\mathrm{BSMD}$ 를 산출한 후 다양한 조건확률의 분석을 통해 금융기관의 안정성을 측정한다. $\mathrm{BSMD}$ 는 개별 금융기관들의 재무곤경 확률을 바탕으로 산출되는데 있어 기간이 경과함에 따라 변하는 재무곤경 가능성인 시간가변적 재무곤경 의존성도 포함시킨다. 이를 위해서는 거시 경제위험 요인도 함께 고려해야 하므로 CIMDO(Consistent Information Multivariate Density Optimization) 방식을 통해 경기순환도 고려하는 $\mathrm{BSMD}$ 를 활용한다. 이 같이 $\mathrm{BSMD}$ 을 통해 결합재무 곤경확률 $(\mathrm{JPoD})$ 이 산출되므로 $\mathrm{JPoD}$ 는 $P(X|Y| Z)$ 로 정의할 수 있으며 다음 식 (2)를 활용해 측정된다.10)

$$
\int_{x_{d}^{z}}^{\infty} \int_{x_{d}^{y}}^{\infty} \int_{x_{d}^{x}}^{\infty} \hat{p}(x, y, z) d x d y d z=J P o D
$$

여기서 $x, y, z$ 는 금융기관 $\mathrm{X}, \mathrm{Y}, \mathrm{Z}$ 자산의 로그전환 수익률이고 $x_{d}^{i}$ 는 금융기관 $\mathrm{i}$ 가 재무적 곤경에 처하는 경계점인 $\mathrm{x}$ 를 의미한다.

사모펀드 증가율과 금융시장, 금융기관의 수익률 및 금융안정지표간의 동적 선행관계는 $\mathrm{VAR}$ 모형을 활용한 그랜저인과관계 분석을 통해 살펴본다. 검증하고자 하는 두 가지 형태의 변수와 시장의 변동성을 설명하는 VKOSPI지수를 통제변수로 하여 다음 식 (3)과 같은 VAR 모형을 설정한 후 시차 1 시차 6 까지를 적용해 두 변수간 그랜저인과관계를 도출한다.

$$
\begin{aligned}
& x_{t}=c+\sum_{i=1}^{P} \zeta_{i} x_{t-i}+\sum_{i=1}^{P} \lambda_{i} y_{t-i}+\sum_{i=1}^{P} \theta_{i} V I X_{t-i}+\epsilon_{t} \\
& y_{t}=\alpha+\sum_{i=1}^{P} \beta_{i} y_{t-i}+\sum_{i=1}^{P} \gamma_{i} x_{t-i}+\sum_{i=1}^{P} \delta_{i} V I X_{t-i}+\epsilon_{t}
\end{aligned}
$$

여기서 $y_{t}$ 는 금융시장 지수 수익률, 금융기관 지수 수익률, 금융안정지수(증가율)를, $x_{t}$ 는 증가율로 표시된 다양한 사모펀드 관련 변수를 의미한다. 최근 그랜저인과관계의 정교화를 위해 VAR-(E)GARCH와 같은 모형은 활용하는 연구가 증가하고 있지만 본 연구의 경우 일별이 아닌 월별 자료를 활용함에 따라 변동성 측정을 위한 모형은 사용하지 않는다. 각 변수에 대한 단위근 검정결과 모든 변수에서 $1 \%$ 수준에서 단위근이 존재하지 않는 것으로 밝혀졌다. 다만 $\mathrm{JPoD}$ 는 $10 \%$ 수준에서, 특별자산형 증가율은 $5 \%$ 수준에서 단위근이 존재하지 않는 것으로 나타났다.

사모펀드 증가가 금융안정에 미치는 영향에 대한 분석에서는 그랜저인과관계 분석결과 유의한 것으로 도출된 관계만을 추출, 이 중 사모펀드 증가가 금융시장이나 금융기관 금융안정지표에 선도관계가 존재하는 것만을 분석 대상으로 하였다. 이들 관계에 대해서는 식 (3)에서 $\mathrm{SC}$ 값을

10) JPoD 산출방법에 대한 보다 자세한 내용은 Lee et al.(2012) 참조. 
한국증권학회지 제49권 6호 (2020)

통해 적정차수를 결정하였다.11) 적정차수 하에서 통계적 유의성이 가장 높은 시차의 계수를 도출함으로 변수간 영향을 주는 방향과 정도를 파악한다. 또한 사모펀드 증가가 금융안정에 미치는 영향에 대한 강건성 확보를 위해 충격반응함수와 분산분해도 실시한다. Cholesky를 활용한 충격반응함수를 통해 사모펀드 증가율 충격이 금융시장이나 기관 안정성에 실제로 미치는 영향을 파악하며 금융안정지표 변화에 대한 유형별 사모펀드의 공헌도를 살펴보기 위해 유형별 사모펀드 증가율에 대한 금융안정지표의 분산분해도 실시한다.

사모펀드로의 자금유출입과 관련된 금융업종간 상호연계성은 기본적으로 Billio et al.(2012)이 활용한 주성분 분석과 그랜저 인과관계를 통한 네트워크 분석을 통해 검증을 실시한다.12) 금융업종간 위기의 동적 전이관계는 금융업종간 연계성 정도뿐 아니라 전이 방향도 중요하다. 이에 따라 다음 식 (4)와 같이 2 변수 $\mathrm{VAR}$ 를 활용한 그랜저 인과관계 검증을 통해 금융업종간 상호연계성을 분석한다.

$$
\begin{aligned}
& x_{t}=c+\sum_{n=1}^{p} \delta_{n} x_{t-n}+\sum_{n=1}^{p} \lambda_{n} y_{t-n}+\epsilon_{t} \\
& y_{t}=\alpha+\sum_{n=1}^{p} \beta_{n} y_{t-n}+\sum_{n=1}^{p} \gamma_{n} x_{t-n}+\epsilon_{t}
\end{aligned}
$$

여기서 $x_{t}$ 와 $y_{t}$ 는 일반은행 특수은행 신탁 서민금융기관 보험 증권 여신전문기관의 펀드로의 자금흐름을 나타낸다. 펀드로의 자금흐름과 관련된 금융업종간 그랜저 인과관계에 의한 네트 워크는 다음 식 (5)와 같이 금융업종 상호간 그랜저 인과관계의 표시함수를 통해 파악된다.

$$
(i \rightarrow j)=\left\{\begin{array}{l}
1 \text { if } \text { igrangercauses } j \\
0 \text { otherwise }
\end{array}\right.
$$

이 식에서 금융업종 $i$ 는 금융업종 $j$ 에 대해 그랜저 인과관계가 존재한다고 할 수 있다. 이 같은 표시함수를 통해 $N$ 개 금융업종의 네트워크를 구성할 수 있다. 금융업종간 연계성은 다음 식 (6)과 같이 모든 금융업종 상호간 그랜저 인과관계 $N(N-1)$ 개 중 통계적으로 유의한 인과 관계의 비율로 정의된다.

$$
D G C=\frac{1}{n(n-1)} \sum_{i=1}^{n} \sum_{i \neq j}(i \rightarrow j)
$$

또한 다음 식 (7)과 같은 근접성, 식 (8)과 같은 중심성으로도 특정 금융업종의 시스템내에서의

11) 적정차수란 시계열분석에서 독립변수와 종속변수의 관계 설명에 있어 가장 최적의 시차를 의미한다. 적정차수는 일반적으로 $\mathrm{AIC}$ (Akaike Information Criterion)나 $\mathrm{SC}$ (Schwarz Information Criterion)를 통해 도출하며 $\mathrm{AIC}$ 나 $\mathrm{SC}$ 가 최저값을 갖는 시차를 의미한다. 본 연구의 경우에는 $\mathrm{SC}$ 를 통해 적정시차를 결정하였다. $\mathrm{AIC}$ 의 경우 $\mathrm{SC}$ 에 비해 파라미터의 수를 과대 식별하는 경향이 있어 충격에 대한 영향을 보다 정확하게 고려하기 위해 시차가 비교적 짧은 $\mathrm{SC}$ 를 선택한 것이다.

12) 그랜저 인과관계를 통한 네트워크 분석에 대한 보다 자세한 내용은 $\mathrm{Yi}(2015,2017 \mathrm{~b})$ 참조. 
The Effect of Private Fund Expansion on Financial Stability

연관성을 파악한다. 근접성이란 특정 금융업종이 시스템 내의 연관성이 있는 모든 다른 금융업종에 도달할 수 있는 최단거리를 의미하며 중심성은 네트워크 내에서의 특정 금융업종의 중요성을 측정한다.

$$
\begin{gathered}
C_{i S=} \sum_{i \neq j} C_{j i}(i \stackrel{C}{\longrightarrow} j) /(\text { Numberof } C-\text { Grangerconnection }) \\
\nu_{i}=\sum_{i=1}^{n}[A]_{i j} \nu_{j}
\end{gathered}
$$

여기서 $C_{i, j}$ 를 금융기관 $i$ 와 $j$ 간의 최단 거리를 나타내며 $\nu$ 는 벡터, $A$ 는 인접행렬을 나타낸다.

\section{4. 연구 결과}

\section{1 사모펀드 시장규모 확대와 금융시장 수익률}

사모펀드의 시장규모 증대와 금융시장 수익률간의 그랜저인과관계는 <표 $3>$ 에 정리되어 있다. 먼저 사모펀드 전체적으로 보았을 때 사모펀드 증가율은 금융시장 수익률에 대해 그랜저 인과관계가 존재하는 것으로 나타났다. 사모펀드 증가율은 주식, 채권, 파생, 부동산, 대체투자 등 모든 시장에 대해 선도관계를 시현했다. 특히 사모펀드 증가율은 주식, 채권, 대체투자시장에 대해 비교적 강한 그랜저인과 관계를 보였다. 주식시장과 대체투자시장에 대해서는 $2,3,4$ 기에 모두 5\% 수준에서 통계적 유의성을 나타냈다. 또한 사모펀드 시장 증가율은 부동산시장에 대해서는 3 개월의 시차를 두고 선도관계를 보였다. 반면 역의 관계는 대부분 성립하지 않았다. 즉 금융시장의 수익률은 사모펀드 증가율을 전반적으로 선도하지 않는 것으로 나타났다. 채권 시장의 KIS종합채권이나 부동산 시장의 아파트매매지수 증가율은 사모펀드 전체 증가율을 선도하지 않았다. 다만 주식과 대체투자 등 일부 금융시장에서는 사모펀드 증가율을 선행하는 경우도 존재했다.13)

사모펀드 유형별로는 규모 증대와 금융시장 수익률간의 인과관계가 상이하게 나타났다. 일단 채권형 사모펀드의 경우에는 채권시장 수익률에 강한 선도관계를 보였다. 채권형은 KIS채권종합, 스프레드, 국채 수익률 등 채권시장 수익률을 나타내는 모든 변수에 대해 $1 \%$ 수준에서 통계적으로 유의한 그랜저인과관계를 시현했다. 반면 주식형이나 주식혼합형, 채권혼합형, 부동산형, 특별 자산형은 펀드 규모 증대가 해당 시장의 수익률과 인과관계를 보이지 않았다. 다만 증권형의 경우는 채권형이 다수를 차지하고 있어 증권 시장 수익률에 유의한 인과관계가 존재하는 것으로 보인다. 금융시장 수익률과 사모펀드 규모 증대간의 그랜저인과관계는 유형별로 더욱 복잡하게

13) 사모펀드 증가율과 금융시장 수익률간에는 변수의 내생성으로 인해 상호 인과관계가 존재함으로써 결과해석에 오류가 발생할 수 있는 동시성 편의(simultaneity bias) 가능성이 있다. 이를 통제하는 방법 중 하나는 도구변수(instrument variable)를 활용하는 것이고 본 연구의 경우 시차변수가 일종의 도구변수 역할을 수행했다고 할 수 있다. 실제로 일부 분석결과에서 설명변수와 잔차의 상관계수가 통계적으로 유의하지 않게 도출되어 동시성 편의는 일정부분 통제되었다고 할 수 있다. 
한국증권학회지 제49권 6호 (2020)

도출되었다. 채권형과 부동산형을 제외하고는 관련 시장 수익률이 사모펀드 규모 증대에 별다른 원인관계를 보이지 못했다. 채권형 중에서도 KIS종합채권과 스프레드는 채권형 펀드 증대에 별다른 선도관계를 보이지 않은 반면 국채 수익률은 3 개월의 시차를 두고 채권형 펀드 증대에 기여한 것으로 나타났다. 또한 아파트가격 상승은 부동산형 펀드 규모 증대에 통계적으로 유의하게 선행하는 흥미로운 결과를 도출했다.

〈표 3〉사모펀드 자금증가율과 금융시장 수익률간의 그랜저인과관계 ***, **, *는 각각 $1 \%, 5 \%, 10 \%$ 수준에서 유의성을 나타낸다.

\begin{tabular}{|c|c|c|c|c|c|c|c|}
\hline & 시차 & 1 & 2 & 3 & 4 & 5 & 6 \\
\hline \multirow{10}{*}{$\begin{array}{l}\text { 사모펀드 } \\
\text { 전체 }\end{array}$} & $\mathrm{KOSPI} \rightarrow$ 사모펀드합 & 0.14 & $3.54^{* *}$ & $2.43^{*}$ & $2.35^{*}$ & $2.18^{*}$ & $2.10^{*}$ \\
\hline & 사모펀드합 $\rightarrow \mathrm{KOSPI}$ & $3.31^{*}$ & $3.79^{* *}$ & $3.40^{* *}$ & $2.82^{* *}$ & $2.23^{*}$ & $2.04^{*}$ \\
\hline & $\mathrm{KIS}$ 종합채권 $\rightarrow$ 사모펀드합 & 0.12 & 0.06 & 0.46 & 0.95 & 1.14 & 1.05 \\
\hline & 사모펀드합 $\rightarrow \mathrm{KIS}$ 종합채권 & $3.90^{*}$ & $3.60^{* *}$ & $2.35^{*}$ & $2.67^{* *}$ & $2.19^{*}$ & $2.46^{* *}$ \\
\hline & 코스피200선물 $\rightarrow$ 사모펀드합 & 0.48 & $3.24^{* *}$ & $2.15^{*}$ & 1.85 & 1.60 & 1.75 \\
\hline & 사모펀드합 $\rightarrow$ 코스피 200 선물 & 1.84 & $2.76^{*}$ & $2.72^{* *}$ & $2.44^{*}$ & $1.91^{*}$ & $1.89^{*}$ \\
\hline & 아파트매매지수 $\rightarrow$ 사모펀드합 & 0.00 & 0.22 & 0.14 & 0.66 & 1.51 & $2.26^{* *}$ \\
\hline & 사모펀드합 $\rightarrow$ 아파트매매지수 & 0.54 & 1.13 & $2.51^{*}$ & $2.87^{* *}$ & $2.24^{*}$ & 1.76 \\
\hline & 대체투자BM $\rightarrow$ 사모펀드합 & 0.12 & $3.58^{* *}$ & $2.45^{*}$ & $2.38^{*}$ & $2.21^{*}$ & $2.15^{*}$ \\
\hline & 사모펀드합 $\rightarrow$ 대체투자BM & $3.22^{*}$ & $3.80^{* *}$ & $3.41^{* *}$ & $2.81^{* *}$ & $2.23^{*}$ & $2.05^{*}$ \\
\hline \multirow{14}{*}{$\begin{array}{l}\text { 증권형 } \\
\text { 주식형 } \\
\text { 채권형 }\end{array}$} & 주식혼합BM $\rightarrow$ 증권형 & 0.93 & 1.59 & 1.93 & 1.30 & 1.60 & $2.26^{* *}$ \\
\hline & 증권형 $\rightarrow$ 주식혼합BM & $3.76^{*}$ & $4.03^{* *}$ & $3.75^{* *}$ & $2.83^{* *}$ & $2.54^{* *}$ & $2.00^{*}$ \\
\hline & $\mathrm{KOSPI} \rightarrow$ 주식형 & 0.43 & 0.37 & 0.68 & 0.83 & 0.65 & 1.44 \\
\hline & 주식형 $\rightarrow \mathrm{KOSPI}$ & 0.00 & 0.00 & 0.08 & 0.13 & 0.09 & 0.22 \\
\hline & 주식혼합BM $\rightarrow$ 주식혼합형 & 0.06 & 0.08 & 0.06 & 0.10 & 0.26 & 0.30 \\
\hline & 주식혼합형 $\rightarrow$ 주식혼합BM & 1.68 & 1.17 & 1.00 & 1.14 & 1.59 & 1.58 \\
\hline & KIS종합채권 $\rightarrow$ 채권형 & 0.46 & 1.12 & 0.83 & 0.65 & 0.94 & 0.67 \\
\hline & 채권형 $\rightarrow \mathrm{KIS}$ 종합채권 & 2.61 & $5.44^{* * *}$ & $6.79^{* * *}$ & $5.15^{* * *}$ & $4.19^{* * *}$ & $3.92^{* * * *}$ \\
\hline & 스프레드 $\rightarrow$ 채권형 & 0.01 & 0.58 & 1.12 & 1.49 & $2.21^{*}$ & 1.26 \\
\hline & 채권형 $\rightarrow$ 스프레드 & $16.10^{* * *}$ & $9.67^{* * *}$ & $8.29^{* * *}$ & $6.11^{* * *}$ & $5.87^{* * *}$ & $5.70^{* * * *}$ \\
\hline & 국채 $\rightarrow$ 채권형 & 0.55 & 0.50 & $2.30^{*}$ & $2.02^{*}$ & $2.53^{* *}$ & $2.69^{* *}$ \\
\hline & 채권형 $\rightarrow$ 국채 & $2.82^{*}$ & $6.60^{* * *}$ & $5.72^{* * *}$ & $4.28^{* * *}$ & $3.09^{* *}$ & $3.24^{* * *}$ \\
\hline & 채권혼합 $\mathrm{BM} \rightarrow$ 채권혼합형 & 1.39 & 0.79 & 1.63 & 1.38 & 1.29 & 1.05 \\
\hline & 채권혼합형 $\rightarrow$ 채권혼합BM & 0.01 & 0.03 & 1.32 & 1.12 & 1.20 & 0.98 \\
\hline \multirow{6}{*}{$\begin{array}{l}\text { 기타 } \\
\text { 파생형 } \\
\text { 부동산형 } \\
\text { 특별자산형 }\end{array}$} & 코스피200선물 $\rightarrow$ 파생형 & 0.04 & 0.01 & 0.11 & 0.12 & 0.85 & 0.91 \\
\hline & 파생형 $\rightarrow$ 코스피200선물 & 0.26 & 0.56 & 0.23 & 0.27 & 0.20 & 0.63 \\
\hline & 아파트매매지수 $\rightarrow$ 부동산형 & $5.78^{* *}$ & $5.56^{* * *}$ & $4.47^{* * *}$ & $3.97^{* * *}$ & $3.55^{* * *}$ & $2.92^{* *}$ \\
\hline & 부동산형 $\rightarrow$ 아파트매매지수 & 0.04 & 0.30 & 0.40 & 0.36 & 0.27 & 0.36 \\
\hline & 대체투자BM $\rightarrow$ 특별자산형 & 0.20 & 0.22 & 0.61 & 0.82 & 0.73 & 0.54 \\
\hline & 특별자산형 $\rightarrow$ 대체투자BM & 0.10 & 0.48 & 0.88 & 1.18 & 1.07 & 1.61 \\
\hline
\end{tabular}

사모펀드 시장 규모 확대가 금융시장 수익률에 미치는 직접적인 영향은 <표 $6>$ 의 패널 $\mathrm{A}$ 에 정리되어 있다. <표 3>에서 사모펀드 규모 증대가 금융시장 수익률에 유의하게 그랜저인과 하는 경우만을 추출해 실질적으로 영향을 미치는 시기와 정도를 보다 자세히 살펴보았다. 분석결과 
The Effect of Private Fund Expansion on Financial Stability

사모펀드 수탁고의 증가는 전반적으로 금융시장 수익률에 악영향을 미치는 것으로 밝혀졌다. 특히 주식시장과 대체투자 시장에서 부정적인 효과가 두드러지게 나타났다. 주식시장의 경우 KOSPI 지수를 종속변수로 하는 경우 계수는 시차 2에서 -0.3458을 기록, 사모펀드 전체 수탁고가 $1 \%$ 증가하는 경우 2 개월 후 시장수익률은 $0.35 \%$ 하락한다는 경제적 의미를 보여주었다.14) 이 같이 사모펀드 증가로 인한 주식시장 수익률 하락은 최근 급증하고 있는 헤지펀드의 경우 가장 일반적인 롱-숏 투자전략을 달성하기 위해 다량의 공매도거래를 수행하는 것도 한 이유로 추론되고 있다. 실제로 자산운용사의 대차거래 차입비율은 주식수익률에 단기적으로 악영향을 주는 것으로 드러났다. 자산운용사의 대차거래 차입비율은 주식수익률에 시차 1 과 시차 2 에서 그랜저인과관계가 존재하였으며 VAR 모형을 통해 분석한 결과 시차 1 에서는 -0.60 , 시차 2 에서는 -0.76 의 통계적으로 유의한 계수를 보여 주식시장 수익률을 하락시키는 것으로 밝혀졌다.15) 또한 대체시장 수익률 하락도 최근 저금리로 인한 투자처 발굴차원에서 대체투자에 대한 수요가 증가하면서 대체자산의 수익률이 하락하고 있는 것으로 유추할 수 있다. 반면 사모펀드 증가가 채권시장과 부동산시장 수익률에는 양의 관계를 보였다. 채권은 동차에서, 부동산 시장은 수익률이 유의하게 증가하는 것으로 나타났다. 부동산의 경우 사모펀드 증가는 서울 아파트매매지수를 8개월이라는 시차를 두고 상당 폭 끌어올리는 것으로 밝혀졌다.

유형별로는 채권형 사모펀드가 채권시장 수익률 증대에 우호적인 관계를 보였다. 채권형 펀드의 증가는 KIS종합채권지수의 수익률과 시차 0 에서 강한 양의 관계를 보였으며 스프레드에 대해서는 시차 1 에서 강한 음의 관계를 나타냈다. 반면 국채수익률과는 관계가 없었다. 채권시장의 수익률을 표시하는 지수 간에 상반된 결과를 보인 것은 논리적이라고 할 수 있다. 예컨대 금리가 하락하는 경우 채권가격은 상승함에 따라 채권에 대한 투자수익률은 증가하게 된다. 이에 따라 종합채권지수는 양의 수익률을 시현하는 반면 국채수익률이나 금리스프레드는 하락하게 되는 것이다. 한편 증권형 펀드는 주식혼합벤치마크에 대해 양의 관계를 갖는 것으로 나타났다. 증권형에서 채권형이 차지하는 비율이 높고 주식혼합벤치마크가 KOSPI지수와 KIS종합채권 지수의 균등평균으로 산출되었기 때문으로 풀이된다.

이 같은 사모펀드 증가율이 금융시장에 미치는 영향은 충격반응함수에서 보다 명확하게 시현된다. <그림 $3>$ 은 사모펀드 증가율이 금융시장 수익률에 그랜저인과하는 9 가지 경우에

14) 주식시장과 대체투자 시장의 수익률이 사모펀드 수탁고 증가에 부정적인 영향을 미치는 역인과관계도 존재하였다. 다만 $\mathrm{VAR}$ 모형을 통해 변수간 직접적인 영향정도를 분석한 결과 주식시장의 수익률이 사모펀드 수탁고에 미치는 영향은 시차 2에서 $-0.1069(\mathrm{t}=-1.76)$, 대체투자 시장 수익률이 사모펀드 수탁고에 미치는 영향은 시차 2에서 $-0.1797(\mathrm{t}=-1.85)$ 로 $10 \%$ 수준에서 유의성을 보여 사모펀드 수탁고 증가가 주식시장 및 대체투자 시장의 수익률에 미치는 영향에 비해 계수가 작았고 유의성도 낮았다.

15) 사모펀드 규모 확장이 주식 수익률 하락을 이끄는 하나의 경로로 헤지펀드의 공매도 거래와 주식수익률간의 관계를 살펴볼 수 있다. 하지만 헤지펀드의 공매도 자료는 존재하지 않아 대신 참여자별 대차거래내역 중 자산운용사의 차입비율이 주식수익률에 미치는 영향을 분석했다. 즉 공모펀드는 공매도가 금지되어 있으므로 자산운용사의 공매도는 사모펀드에 국한되어질 것이므로 전체 대차거래에서 자산운용사의 대차거래 비율 분석을 통해 간접적으로나마 사모펀드 규모 확장이 주식수익률 하락을 이끄는 경로 중 하나로 파악했다. 
대한 충격반응함수 결과이다. 사모펀드 전체 수탁고의 충격에 대한 KIS종합채권 수익률의 반응(response of $\mathrm{I} 2$ to F1)은 시차 2에서, 사모펀드 전체 수탁고의 충격에 대한 아파트매매지수 증가율(response of I8 to F1)은 시차 4 이후 유의한 양의 관계를 보이고 있다. 또한 채권형 펀드의 충격에 대한 KIS종합채권 수익률(response of I2 to F5)은 시차 2 에서 양의 관계, 스프레드(response of I3 to F5)는 시차 2에서 음의 관계를 보이는 그래프를 도출했다. 이 밖에 다른 그래프는 시차별로 상하한선이 0 을 벗어나지 않아 사모펀드 증가의 충격에 따른 개별 금융시장 수익률의 변화가 통계적으로 유의하지 않는 것으로 나타났다.16)

〈그림 3〉 사모펀드 증가율이 금융시장에 미치는 영향에 대한 충격반응함수
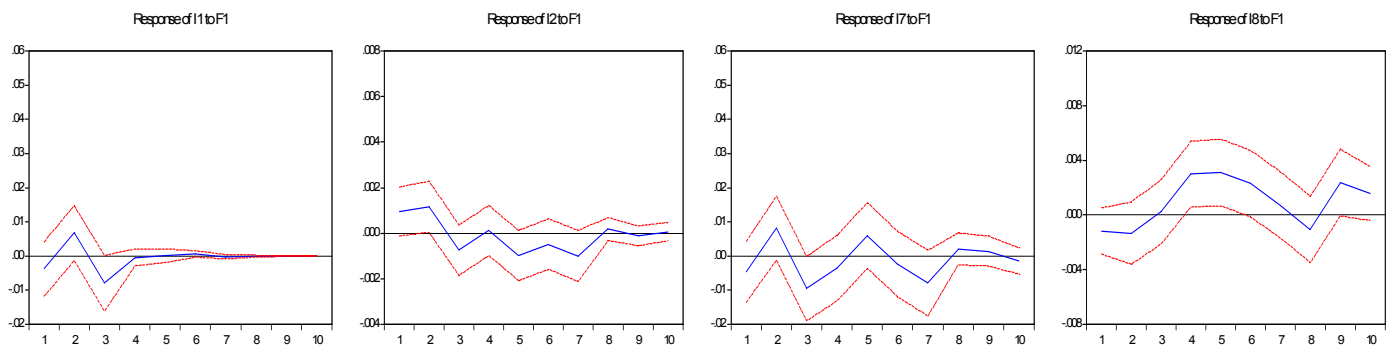

Pesporæed 19toF1

Responsed 15 toF2

Pexpormed $1210 \mathrm{~F}$

Responeed 13 tor 5
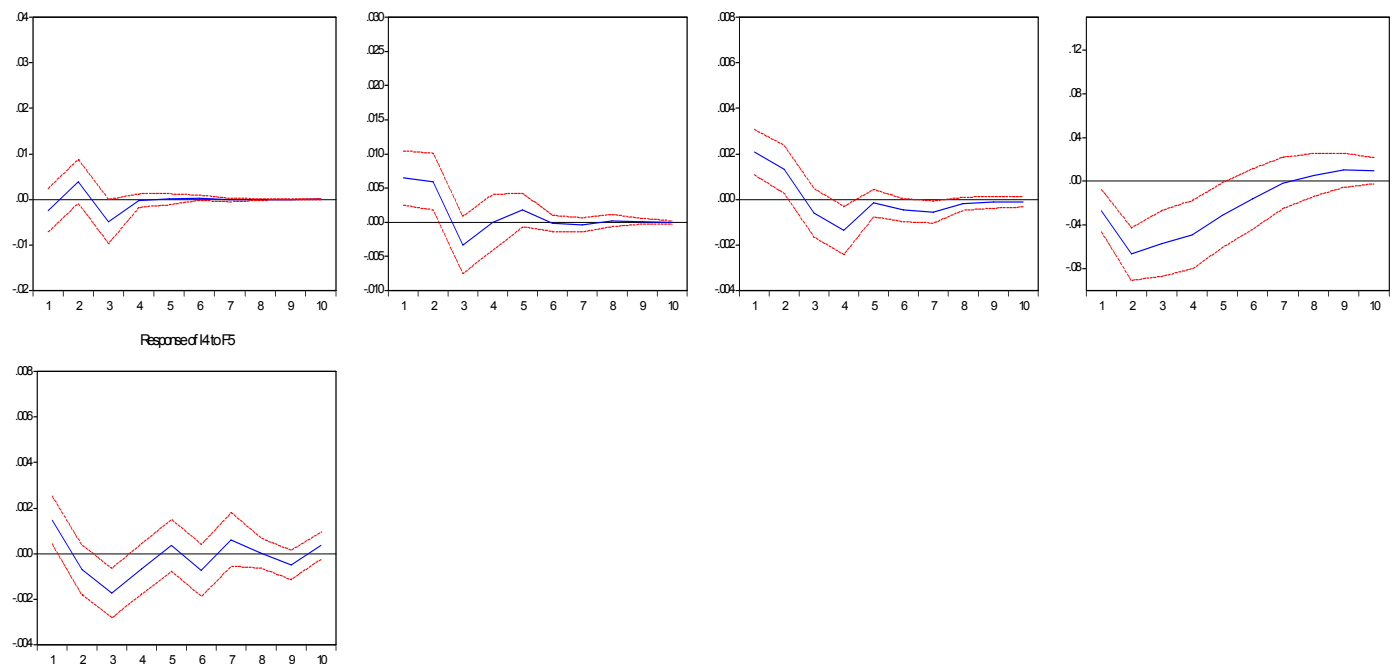

\section{2 사모펀드 시장규모 확대와 금융기관 수익률}

사모펀드 증가와 금융기관 수익률간의 관계는 전반적으로 사모펀드 증가율이 금융기관 수익률에 대해 그랜저인과하기보다 금융기관 수익률이 사모펀드 증가율에 대해 그랜저인과하는 하는 것으로 밝혀졌다. 이는 $\mathrm{ECB}(2008)$ 의 연구결과와 일치하는 것으로 사모펀드의 금융안정성

16) 충격반응함수에서 중간선은 독립변수의 충격에 대한 종속변수의 변화를 계수화 한 것이며 상하한선은 계수의 $95 \%$ 신뢰구간에서의 상한과 하한을 의미한다. 
The Effect of Private Fund Expansion on Financial Stability

저해 가능성이 논란에 그칠 수 있음을 보여주는 것이라고 할 수 있다. 특히 보험과 기타금융업종의 주가수익률이 사모펀드 증가를 선도하는 경향이 뚜렷하게 나타났다. 보험 수익률은 시차 1 을 제외한 전 시차에서, 기타금융 수익률은 시차 1 부터 시차 4 까지 사모펀드 증가에 선행하는 것으로 나타났다. 금융업종 전체 수익률은 시차 2 와 3 , 그리고 5 에서 사모펀드 증가율을 그랜저인과하였다. 반면 사모펀드 증가율이 금융기관 수익률을 선도하는 현상은 지극히 일부의 관계에서만 나타났다. 사모펀드 증가율은 금융업종 전체에 대해서는 시차 3 에서만, 은행에 대해서는 시차 2 4에서, 보험에는 시차 1에서만 유의한 그랜저인과관계를 보였다. 다만 기타금융 수익률에 대해서는 사모펀드 증가가 비교적 높은 인과관계를 보였다. 이 같은 결과는 <표 $4>$ 에 정리되어 있다.

유형별로 살펴보면 부동산형의 경우 금융업종 수익률이 사모펀드 증가율을 선도하는 현상이 두드러지게 나타났다. 은행을 제외한 금융업종 전체, 증권, 보험, 기타금융기관의 수익률이 사모펀드 증가에 대해 강한 그랜저인과관계를 보였다. 반면 사모펀드 증가율이 금융기관의 수익률을 선도하는 금융업종은 존재하지 않았다. 하지만 채권형의 경우는 부동산형과 정반대의 결과를 보였다. 즉 채권형의 경우에는 사모펀드 증가율이 증권과 기타금융을 제외하고 금융업종 주가수익률에 강한 그랜저인과관계를 시현했다.

특히 채권형 펀드 증가는 금융업종 전체, 은행, 보험사 수익률에 대해 모든 시차에서 강한 선도관계를 보였다. 금융기관의 수익률에 대해 채권형 펀드의 흐름은 선행하고 부동산형 펀드의 흐름은 후행하는 것은 상당히 흥미로운 결과라고 할 수 있다. 이는 금융시장이 실물경제에 약 6 개월간의 시차를 두고 영향을 미친다는 많은 선행 연구결과와 일치하는 것이다. 또한 채권형 펀드는 금융기관의 수익률을 선도하는데 비해 사모펀드 전체적으로는 금융기관의 수익률에 후행하는 현상도 채권형 펀드가 사모펀드 중에 차지하는 비율이 가장 높은 현실을 감안했을 때 주목할 만 하다고 할 수 있다. 이는 금융기관 수익률 결정에 채권형 펀드의 기여부분이 크지 않음을 반증하는 결과라고 할 수 있다. 한편 주식형과 특별자산형에서는 사모펀드 증가율과 금융기관 수익률간에 별다른 인과관계를 보이지 않았다.

이에 따라 사모펀드 시장 확대가 금융기관 수익률에 미치는 직접적인 영향은 전반적으로 제한적인 것으로 밝혀졌다. 사모펀드 증가가 금융기관 수익률에 하나의 시차에서라도 그랜저인과 관계가 존재하는 경우에 대한 추가적 분석 결과 <표 $6>$ 의 패널 $\mathrm{B}$ 에서와 같이 사모펀드 전체의 증가는 금융기관 수익률에 부정적인 영향을 미쳤으나 통계적으로 유의한 수준은 아니었다. 다만 기타금융업종의 수익률에 대해서는 시차 1 에서 오히려 유의한 양의 관계를 보였다.

하지만 유형별로 구분하여 살펴보면 펀드전체의 경우와 다소 상이한 결과를 도출했다. 즉 채권형의 경우 펀드의 증가는 1 개월 후 금융업 전체나 은행, 보험사 수익률의 증대로 이어지는 것으로 밝혀졌다. 또한 주식형 사모펀드의 경우에도 보험사의 수익률과 동차에서 유의한 정관계를 보였다. 특정유형의 증가가 금융기관의 수익성을 개선하는 이 같은 현상은 금융기관도 해당 유형 펀드를 보유하고 있기 때문으로 추론된다. 실제로 투자자산이 다른 금융사에 비해 상대적으로 많은 보험사의 경우 주식형과 채권형 펀드의 증가가 보험사의 수익률을 견인하는 것으로 나타났다. 
한국증권학회지 제49권 6호 (2020)

〈표 4〉사모펀드 자금증가율과 금융업종 주가수익률간의 그랜저인과관계 ***, ** *는 각각 $1 \%, 5 \%, 10 \%$ 수준에서 유의성을 나타낸다.

\begin{tabular}{|c|c|c|c|c|c|c|c|}
\hline & & 1 & 2 & 3 & 4 & 5 & 6 \\
\hline \multirow{10}{*}{ 사모펀드 전체 } & $\leftarrow$ 긍ㅇ어조 & 1.21 & $4.46^{* *}$ & $2.80^{* *}$ & 1.98 & $1.96^{*}$ & 1.77 \\
\hline & $\rightarrow$ 믐융업종 & 2.29 & 2.07 & $2.67^{* *}$ & 1.58 & 1.38 & 1.10 \\
\hline & $\leftarrow$ o 해 & 1.66 & $3.06^{* *}$ & 2.01 & 1.45 & 1.80 & 1.46 \\
\hline & $\rightarrow$ 은행 & 2.41 & $2.71^{*}$ & $2.70^{* *}$ & $2.08^{*}$ & 1.64 & 1.21 \\
\hline & $\leftarrow$ 즈궈 & 1.18 & 1.27 & $2.40^{*}$ & 1.93 & $1.97^{*}$ & $2.51^{* *}$ \\
\hline & $\rightarrow$ 증권 & 2.14 & 1.98 & 1.54 & 1.29 & 0.90 & 0.96 \\
\hline & $\leftarrow$ 허너 & 0.01 & $4.05^{* *}$ & $2.52^{*}$ & $2.82^{* *}$ & $2.60^{* *}$ & $2.30^{* *}$ \\
\hline & $\rightarrow$ 보험 & $4.00^{* *}$ & 1.96 & 1.43 & 1.60 & 2.17 & $2.01^{*}$ \\
\hline & $\leftarrow$ 기타그으 & $3.90^{*}$ & $4.97^{* * *}$ & $3.67^{* *}$ & $3.11^{* *}$ & $2.99^{* *}$ & $2.34^{* *}$ \\
\hline & $\rightarrow$ 기타믐융 & $7.29^{* * * *}$ & $4.75^{* *}$ & $2.84^{* *}$ & $2.07^{*}$ & 1.86 & 1.32 \\
\hline \multirow{10}{*}{ 주식형 } & & 0.27 & 0.15 & 0.61 & 1.37 & 1.39 & $1.91^{*}$ \\
\hline & $\rightarrow$ 立ㅇㅇㅇ업송 & 0.04 & 0.10 & 0.26 & 0.24 & 0.33 & 0.44 \\
\hline & $\leftarrow$ 으해 & 0.04 & 0.04 & 0.29 & 0.52 & 0.40 & 0.65 \\
\hline & $\rightarrow$ 은행 & 0.07 & 0.07 & 0.07 & 0.16 & 0.51 & 0.51 \\
\hline & $\leftarrow$ 즈ㄱㅝㅝ & 1.39 & 1.27 & 1.40 & 1.44 & 1.34 & 1.61 \\
\hline & $\rightarrow$ 증권 & 1.51 & 0.67 & 0.90 & 0.51 & 0.70 & 0.89 \\
\hline & $\leftarrow$ & 0.72 & 0.37 & 0.25 & 0.99 & 0.93 & 1.12 \\
\hline & $\rightarrow$ 보험 & 0.13 & 0.06 & $2.61^{*}$ & $2.05^{*}$ & 1.51 & 1.49 \\
\hline & $\leftarrow$ 기타그으 & 0.05 & 1.30 & 1.46 & 1.09 & 1.34 & 1.40 \\
\hline & $\rightarrow$ 기타믐융 & 0.36 & 0.27 & 0.39 & 0.48 & 0.87 & 1.09 \\
\hline \multirow{10}{*}{ 채권형 } & $\leftarrow$ 그으어조 & 1.78 & 0.85 & 0.90 & 1.08 & 1.48 & 1.82 \\
\hline & $\rightarrow$ 금융업종 & $7.14^{* * *}$ & $4.12^{* *}$ & $4.32^{* * *}$ & $3.89^{* * *}$ & $3.06^{* *}$ & $2.17^{*}$ \\
\hline & & 0.37 & 0.45 & 1.77 & 1.73 & 1.66 & $1.75^{*}$ \\
\hline & $\rightarrow$ 은행 & $7.73^{* * *}$ & $4.08^{* *}$ & $5.42^{* * *}$ & $4.74^{* * *}$ & $4.63^{* * *}$ & $3.38^{* * * *}$ \\
\hline & $\leftarrow z$ & 0.88 & 0.42 & 0.76 & 0.78 & 1.29 & $2.04^{*}$ \\
\hline & $\rightarrow$ 증권 & $2.75^{*}$ & 1.90 & 1.18 & 1.73 & 1.29 & 1.01 \\
\hline & & 1.46 & 1.14 & 1.05 & 0.97 & 1.38 & 1.29 \\
\hline & $\rightarrow$ 보험 & $4.07^{* *}$ & $2.68^{*}$ & $3.00^{* *}$ & $2.31^{*}$ & $2.24^{*}$ & $1.95^{*}$ \\
\hline & $\leftarrow$ 기타금유 & 1.50 & 1.17 & 0.80 & 0.87 & 1.26 & 1.02 \\
\hline & $\rightarrow$ 기타믐융 & 2.36 & 1.51 & 1.82 & 1.44 & 1.32 & 1.27 \\
\hline \multirow{10}{*}{ 부동산형 } & $\leftarrow_{\text {극. }}$ & $3.90^{*}$ & $3.30^{* *}$ & $3.50^{* *}$ & $2.79^{* *}$ & $4.14^{* * *}$ & $3.34^{* * * *}$ \\
\hline & $\rightarrow \overline{\bar{D}}$ & 0.29 & 1.80 & 1.31 & 0.84 & 1.48 & 1.47 \\
\hline & $\leftarrow$ & 0.77 & 1.07 & 1.17 & 0.94 & 1.55 & 1.30 \\
\hline & $\rightarrow$ & 0.29 & 1.04 & 0.76 & 0.70 & 1.31 & 1.13 \\
\hline & $\leftarrow$ & $3.50^{*}$ & $2.91^{*}$ & $3.34^{* *}$ & $2.29^{*}$ & $3.19^{* * *}$ & $2.75^{* *}$ \\
\hline & $\rightarrow$ & 0.00 & 0.42 & 0.53 & 1.16 & 1.24 & 1.35 \\
\hline & $\leftarrow$ & $3.63^{*}$ & $2.91^{*}$ & $3.56^{* *}$ & $2.67^{* *}$ & $3.62^{* * *}$ & $2.84^{* *}$ \\
\hline & $\rightarrow^{\text {보 }}$ & 1.69 & 1.65 & 0.66 & 1.42 & 1.05 & 1.63 \\
\hline & $\leftarrow$ & $4.39^{* *}$ & $5.36^{* * *}$ & $4.02^{* * *}$ & $3.45^{* *}$ & $3.08^{* *}$ & $3.54^{* * *}$ \\
\hline & $\rightarrow^{71}$ & 0.46 & 0.46 & 0.39 & 0.80 & 0.94 & 0.88 \\
\hline \multirow{10}{*}{ 특별자산형 } & & 0.63 & 0.05 & 0.43 & 0.81 & 1.12 & 0.96 \\
\hline & $\rightarrow \overline{\bar{D}}$ & 0.00 & 0.55 & 1.12 & 1.59 & 1.26 & 1.27 \\
\hline & & 1.01 & 0.27 & 0.34 & 0.22 & 0.34 & 0.45 \\
\hline & $\rightarrow$ & 0.38 & 1.31 & 1.22 & 2.19 & 1.78 & 1.45 \\
\hline & $\leftarrow$ & 0.59 & 1.23 & 1.50 & 1.15 & 1.19 & 0.94 \\
\hline & $\rightarrow$ 증권 & 0.02 & 0.27 & 0.87 & 1.47 & 1.18 & $1.95^{*}$ \\
\hline & & 0.07 & 1.45 & 1.14 & 1.95 & 2.01 & 1.75 \\
\hline & $\rightarrow$ 보험 & 0.06 & 0.48 & 0.18 & 0.16 & 0.18 & 0.44 \\
\hline & $\leftarrow$ & 0.01 & 0.75 & 1.08 & 2.22 & $1.90^{*}$ & 1.58 \\
\hline & $\rightarrow$ & 1.00 & 0.76 & 1.68 & 2.23 & 1.70 & 1.32 \\
\hline
\end{tabular}


The Effect of Private Fund Expansion on Financial Stability

사모펀드 증가가 금융기관 수익률에 미치는 영향은 <그림 $4>$ 와 같이 충격반응 함수 결과에서 보다 명확하게 나타난다. 충격반응 함수 분석결과 채권형이 금융업 전체와(response of R1 to F5) 은행 수익률(response of R2 to F5)에 미치는 영향은 유사한 형태를 보이며 채권형 충격 발생 시 시차 1 에서 금융업 전체와 은행 수익률에 양의 유의한 영향을 미치는 것을 보여주고 있다.

〈그림 4〉 사모펀드 증가율이 금융기관에 미치는 영향에 대한 충격반응함수

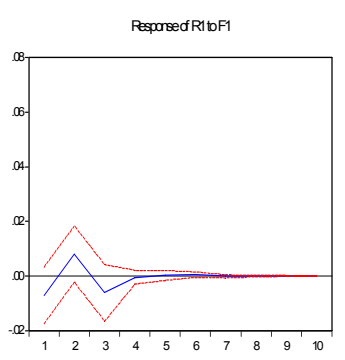

Pesporeed PAt to 3

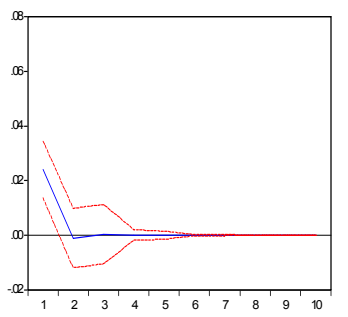

Pesporred R2toF1

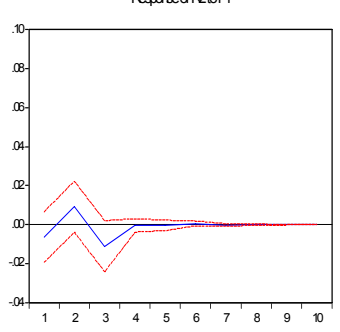

PespreedR1 tor

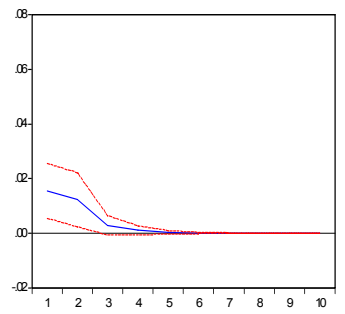

Pesponed f Fto F1

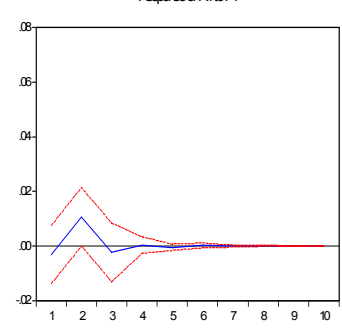

Pesponeed R2tor

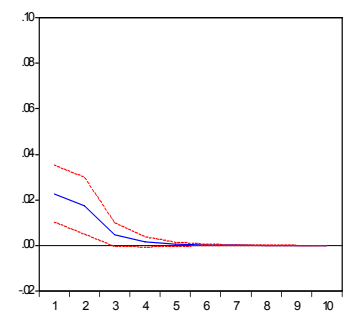

Pesponeed fitiof1

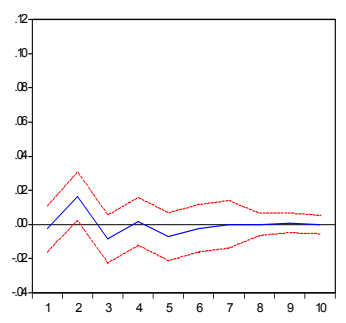

PesponsedPAtor5

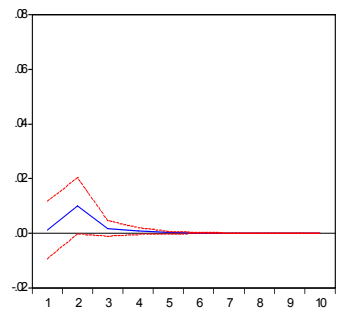

\section{3 사모펀드 시장규모 확대와 금융안정성 지표}

본 절에서는 본 연구의 가장 핵심적인 내용인 사모펀드 증가가 금융안정성에 미치는 영향을 $\mathrm{FSI}$ 지수와 $\mathrm{JPOD}$ 지수 및 그 증가율을 통해 살펴보았다. 먼저 분석결과 사모펀드 시장규모의 확대는 금융안정성에 대해 전반적으로 그랜저인과가 존재하는 것으로 밝혀졌다. 사모펀드 증가는 $\mathrm{FSI}$ 증가율을 제외하고 $\mathrm{FSI}$ 지수, $\mathrm{JPOD}$ 지수, $\mathrm{JPOD}$ 증분에 대해 대부분의 시차에서 선도관계를 보였다. 특히 사모펀드 증가는 $\mathrm{FSI}$ 보다 $\mathrm{JPOD}$ 에 대해 보다 강한 그랜저인과관계를 시현했다. $\mathrm{JPoD}$ 나 $\mathrm{JPoD}$ 증분에 대해서는 모든 시차에서 $1 \%$ 수준의 유의한 인과관계를 보였다. 다양한 경제지표를 감안하여 지수를 산출하는 FSI보다 은행의 도산위험으로 인한 시스템적 리스크를 산출하는 $\mathrm{JPOD}$ 에 유난히 강한 그랜저인과관계를 보인다는 사실은 시사하는 바가 크다고 할 수 있다. 즉 사모펀드 증가가 거시적인 관점의 금융안정성보다 은행 중심의 금융안정성에 관련성이 더 높다는 의미일 수 있다. 이는 사모펀드 증가가 거시경제 지표에 따라 상반되게 영향을 미쳐 여러 거시경제지표를 기반으로 산출한 FSI에 대해서는 그 효과가 상쇄되는 반면, 주로 은행의 $\mathrm{CDS}$ 스프레드에 의해 산출되는 $\mathrm{JPoD}$ 에 대해서는 직접적인 부의 영향을 미치기 때문으로 해석할 수 있다. 예컨대 <표 6> 패널 A에서 보는 바와 같이 사모펀드 증가는 주식시장 수익률에 역관계를 보이는 반면 동시에 스프레드에 대해서도 역관계를 보여 FSI 전체적인 측면에서는 서로 상쇄효과를 얻는 것이다. 하지만 <표 $6>$ 패널 $\mathrm{B}$ 에서 보는 바와 같이 사모펀드 증가는 
한국증권학회지 제49권 6호 (2020)

〈표 5〉 사모펀드 자금증가율과 금융안정지수간의 그랜저인과관계 ***, ** *는 각각 $1 \%, 5 \%, 10 \%$ 수준에서 유의성을 나타낸다.

\begin{tabular}{|c|c|c|c|c|c|c|c|}
\hline & & 1 & 2 & 3 & 4 & 5 & 6 \\
\hline \multirow{8}{*}{ 사모펀드 전체 } & \multirow{2}{*}{$\leftarrow_{\rightarrow} \mathrm{FSI}$} & 1.02 & 0.99 & 1.80 & 1.85 & 1.48 & $2.11^{*}$ \\
\hline & & 0.47 & $3.00^{*}$ & $3.83^{* *}$ & $4.94^{* * *}$ & $3.20^{* * *}$ & $2.86^{* *}$ \\
\hline & \multirow{2}{*}{$\underset{\longrightarrow}{\leftarrow} \mathrm{FSI}$} & 0.19 & 0.05 & 0.04 & 0.27 & 1.37 & 0.98 \\
\hline & & 0.98 & 1.29 & 0.88 & 0.65 & 1.02 & 0.85 \\
\hline & \multirow{2}{*}{$\leftarrow_{\mathrm{JPOD}}$} & 1.12 & 0.61 & $9.03^{* * *}$ & $8.53^{* * *}$ & $6.42^{* * *}$ & $6.37^{* * *}$ \\
\hline & & $14.61^{* * *}$ & $8.83^{* * *}$ & $6.62^{* * *}$ & $4.06^{* * *}$ & $7.90^{* * * *}$ & $6.77^{* * * *}$ \\
\hline & \multirow{2}{*}{$\leftarrow_{\triangle} \triangle \mathrm{JPoD}$} & 0.26 & $5.99^{* * * *}$ & $10.42^{* * *}$ & $8.14^{* * *}$ & $6.85^{* * * *}$ & $5.54^{* * * *}$ \\
\hline & & $8.23^{* * *}$ & $6.95^{* * * *}$ & $5.32^{* * *}$ & $3.87^{* * *}$ & $4.47^{* * *}$ & $3.96^{* * * *}$ \\
\hline \multirow{8}{*}{ 주식형 } & \multirow{2}{*}{${ }_{\rightarrow} \mathrm{FSI}$} & 2.50 & 1.07 & 0.57 & 1.42 & 1.79 & $1.85^{*}$ \\
\hline & & $7.60^{* * *}$ & 1.50 & 1.06 & 1.63 & 0.78 & 0.72 \\
\hline & \multirow{2}{*}{$\underset{\rightarrow}{\leftarrow} \mathrm{FSI}$} & $3.15^{*}$ & 1.05 & 1.43 & 1.31 & 1.37 & 1.43 \\
\hline & & 0.50 & 0.93 & 0.65 & 0.50 & 0.72 & 0.61 \\
\hline & \multirow{2}{*}{$\underset{\mathrm{JPOD}}{\leftarrow}$} & 1.72 & 0.70 & 0.45 & 0.69 & 0.70 & 0.76 \\
\hline & & $4.05^{* *}$ & $2.72^{*}$ & $2.73^{* *}$ & $2.47^{* *}$ & 1.61 & $2.11^{*}$ \\
\hline & \multirow{2}{*}{$\underset{\rightarrow}{\leftarrow} \triangle \mathrm{JPOD}$} & 0.11 & 0.15 & 1.94 & 1.62 & 1.32 & 0.87 \\
\hline & & 1.60 & 0.97 & 1.19 & 1.19 & 0.98 & 1.33 \\
\hline \multirow{8}{*}{ 채권형 } & \multirow{2}{*}{${ }_{\rightarrow} \mathrm{FSI}$} & 2.09 & $3.51^{* *}$ & $2.93^{* *}$ & $2.16^{*}$ & $3.60^{* * * *}$ & $3.15^{* * * *}$ \\
\hline & & $29.08^{* * *}$ & $5.23^{* * * *}$ & $4.98^{* * *}$ & $3.13^{* *}$ & $2.68^{* *}$ & $2.47^{* *}$ \\
\hline & \multirow{2}{*}{$\underset{\rightarrow}{\leftarrow} \mathrm{FSI}$} & 1.10 & 1.28 & 1.16 & 1.62 & $2.58^{* *}$ & $2.70^{* *}$ \\
\hline & & $7.89^{* * *}$ & $4.95^{* * * *}$ & $3.62^{* *}$ & $3.28^{* *}$ & $4.16^{* * *}$ & $4.02^{* * * *}$ \\
\hline & \multirow{2}{*}{$\leftarrow_{\mathrm{JPoD}}$} & 0.95 & 1.10 & 1.31 & 1.03 & $2.30^{* *}$ & 1.43 \\
\hline & & $18.10^{* * *}$ & $10.44^{* * *}$ & $6.49^{* * *}$ & $5.80^{* * *}$ & $4.24^{* * *}$ & $3.22^{* * *}$ \\
\hline & \multirow{2}{*}{$\leftarrow \triangle \mathrm{JPoD}$} & $3.74^{*}$ & 1.78 & 1.37 & 1.53 & $2.73^{* *}$ & $1.97^{*}$ \\
\hline & & $6.82^{* * *}$ & $4.57^{* *}$ & $3.04^{* *}$ & $2.16^{*}$ & 1.80 & 1.54 \\
\hline \multirow{8}{*}{ 부동산형 } & \multirow{2}{*}{$\underset{\rightarrow}{\leftarrow} \mathrm{FSI}$} & $2.81^{*}$ & 1.21 & 1.14 & 1.01 & 1.30 & 1.24 \\
\hline & & 0.01 & 0.18 & 0.21 & 0.21 & 0.24 & 0.21 \\
\hline & \multirow{2}{*}{$\underset{\longrightarrow}{\leftarrow} \triangle \mathrm{FSI}$} & $3.59^{*}$ & $5.72^{* * *}$ & $2.23^{*}$ & 1.65 & 1.25 & 1.63 \\
\hline & & $7.15^{* * *}$ & $5.31^{* * *}$ & $4.91^{* * *}$ & $4.39^{* * *}$ & $3.75^{* * *}$ & $3.34^{* * *}$ \\
\hline & \multirow{2}{*}{$\underset{\mathrm{JPoD}}{\mathrm{J}}$} & 2.62 & 1.10 & 1.06 & 0.92 & 1.81 & $1.82^{*}$ \\
\hline & & 0.01 & 0.10 & 0.21 & 0.61 & 0.93 & 0.88 \\
\hline & \multirow{2}{*}{$\leftarrow_{\triangle} \triangle \mathrm{JPoD}$} & $5.98^{* *}$ & $2.95^{*}$ & $5.22^{* * * *}$ & $3.69^{* * *}$ & $2.75^{* *}$ & $2.97^{* * * *}$ \\
\hline & & 0.13 & $3.17^{* *}$ & $2.50^{*}$ & $2.00^{*}$ & $3.03^{* *}$ & $2.46^{* *}$ \\
\hline \multirow{8}{*}{ 특별자산형 } & \multirow{2}{*}{$\leftarrow_{\mathrm{FSI}}$} & 2.29 & 1.03 & 1.01 & 1.36 & 1.27 & 1.19 \\
\hline & & 0.20 & 0.13 & 0.99 & 1.48 & 0.91 & 0.88 \\
\hline & \multirow{2}{*}{$\underset{\longrightarrow}{\leftarrow} \mathrm{FSI}$} & $8.52^{* * *}$ & 0.47 & 0.56 & $2.27^{*}$ & $3.35^{* * *}$ & $5.30^{* * * *}$ \\
\hline & & $3.61^{*}$ & $5.66^{* * *}$ & $17.44^{* * *}$ & $15.35^{* * *}$ & $9.23^{\text {*** }}$ & $7.76^{* * * *}$ \\
\hline & \multirow{2}{*}{$\underset{\mathrm{JPoD}}{\leftarrow}$} & 1.49 & 0.82 & 0.57 & 0.67 & 0.82 & 0.86 \\
\hline & & 0.65 & 0.45 & 0.59 & 1.23 & 0.96 & 0.83 \\
\hline & \multirow{2}{*}{$\underset{\rightarrow}{\leftarrow} \triangle \mathrm{JPOD}$} & 0.23 & 0.39 & 0.13 & 0.12 & 0.18 & 0.23 \\
\hline & & 0.39 & 0.96 & 2.11 & 1.66 & 1.43 & 1.22 \\
\hline
\end{tabular}


The Effect of Private Fund Expansion on Financial Stability

은행 수익률에 대해 통계적으로 유의하지는 않지만 음의 관계를 보였고 직접적인 분석은 실시하지 않았지만 은행의 $\mathrm{CDS}$ 프리미엄을 확대시켜 $\mathrm{JPoD}$ 를 증가시킨 것으로 유추할 수 있다. 한편 사모펀드 증가율에 대해 $\mathrm{JPOD}$ 의 경우에는 시차 3 부터, $\mathrm{JPOD}$ 증분은 시차 2 부터 그랜저인과관계가 존재해 $\mathrm{JPOD}$ 나 $\mathrm{JPOD}$ 증분은 사모펀드 증가율과 상호간에 선도지연관계가 존재한다고 할 수 있다. 물론 사모펀드 증가의 $\mathrm{JPoD}$ 에 대한 그랜저인과관계가 그 반대의 경우보다는 강하게 나타났다. 이 같은 결과는 <표 5>에 정리되어 있다.

유형별로 살펴보면 역시 채권형이 금융안정성 지표에 가장 강한 선도관계를 보였다. 채권형의 경우 사모펀드 전체와는 달리 $\mathrm{FSI}$ 지수에 대한 인과관계가 $\mathrm{JPOD}$ 만큼 강하게 나타났다. 또한 $\mathrm{FSI}$ 증분에 대해서도 $\mathrm{JPOD}$ 증분 정도의 선도관계를 보였다. 반면 금융안정 지표 중 $\mathrm{FSI}$ 지수를 제외하고는 금융안정 지표가 채권형 사모펀드의 증가를 강하게 선도하는 관계는 보이지 않았다. 즉 FSI지수는 채권형 펀드 증가에 대해 시차 2 이후 모든 시차에서 선도관계를 보인 반면 다른 금융안정 지표는 채권형 펀드 증가에 한 두 시차에서만 선도관계를 보였다.

주식형은 4 개의 금융안정성 지표 중 $\mathrm{JPOD}$ 에 대해서만 선행관계를 보였으며 FSI에 대해서는 시차 1 에서만 인과관계를 보였다. 사모펀드 전체가 $\mathrm{JPOD}$ 에 대해 선행관계를 시현하는데 주식형이 커다란 공헌을 한 것으로 추론된다. 부동산형의 경우에는 금융안정성 지수 자체보다 증가율에

〈그림 5〉사모펀드 증가율이 금융안정성에 미치는 영향에 대한 충격반응함수
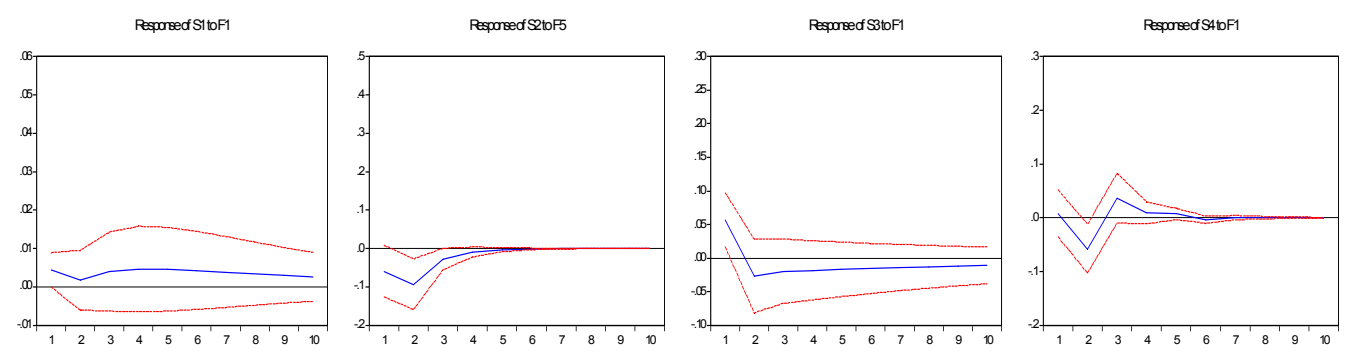

Resporned S t toF

Responed S $10 \mathrm{~F} 1$

Resporeed S3tor

Responed 44 tor 5
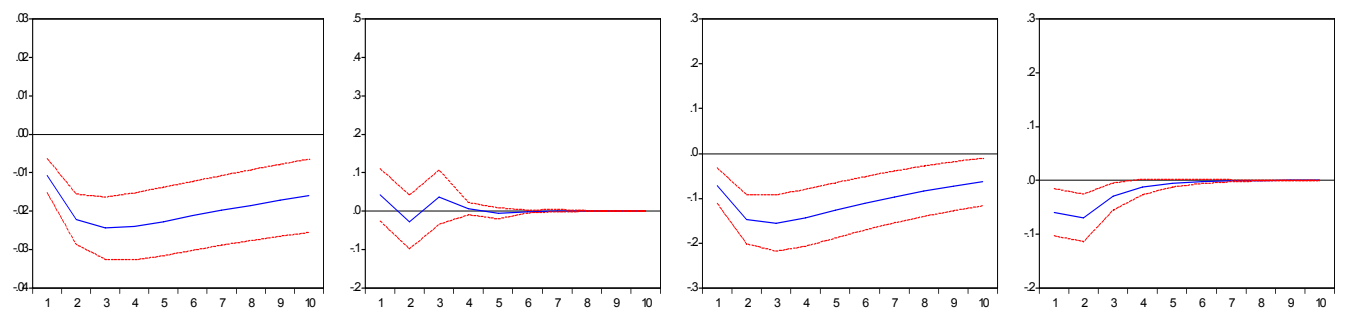

Resporsed S2toF

Responed S4toF

Pespored 210 F
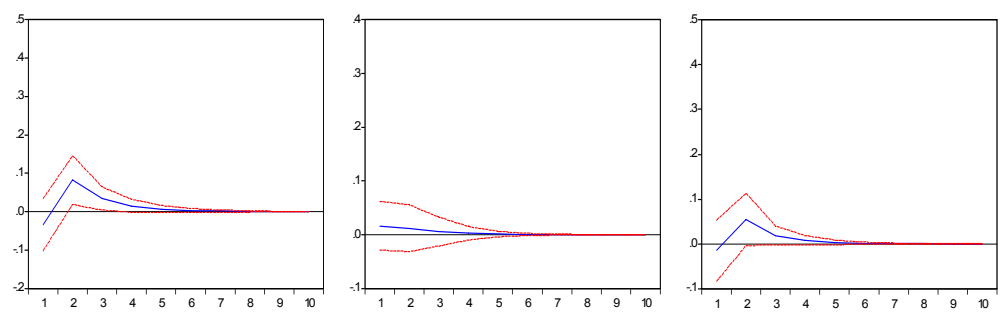
대한 선도관계가 더 뚜렷하게 나타났다. 특히 $\mathrm{JPOD}$ 증분에 비해 $\mathrm{FSI}$ 증분에 강한 선도관계를 보임으로써 부동산형 펀드의 증대가 경제전반의 안정성에 영향을 미칠 수 있을 가능성을 제기했다. 또한 금융안정 지표의 증가율은 부동산형 펀드 증가에 일부 시차에서 선행관계를 보였다. 특히 $\mathrm{JPOD}$ 증분은 모든 시차에서 부동산형 펀드 증가에 그랜저인과하는 것으로 나타났으며 FSI 증분은 시차 1 에서 3 까지에서 인과관계가 존재했다. 특별자산형은 FSI 증분에 대해서만 상호 선도관계가 존재하였다. 물론 특별자산형의 펀드 증가가 FSI 증가율을 선도하는 정도가 그 반대의 경우보다는 강하게 나타났다.

〈표 6〉사모펀드 증가율이 금융시장 및 금융기관 수익률과 금융안정성에 미치는 영향 본 표는 <표 3>, <표 4>, <표 5>에서 사모펀드 시장 규모 확대가 금융시장 및 금융기관 수익률과 금융안정성에 그랜저인과관계가 존재하는 경우에 한해 VAR 모형을 통해 변수들간의 직접적인 영향을 분석한 결과이다. ${ }^{* * *},{ }^{* *},{ }^{*}$ 는 각각 $1 \%, 5 \%, 10 \%$ 수준에서 유의성을 나타낸다.

\begin{tabular}{|c|c|c|c|c|c|c|}
\hline & 독립변수 & 종속변수 & 계수 & $\mathrm{t}$ 값 & 최적시차 & SC \\
\hline \multirow{9}{*}{$\begin{array}{l}\text { 패널 } \mathrm{A}: \\
\text { 금융시장 }\end{array}$} & 사모펀드 전체 & KOSPI & -0.3458 & $-2.06^{* *}$ & 2 & 2 \\
\hline & 사모펀드 전체 & KIS종합채권 & 0.0819 & $3.58^{* * *}$ & 0 & 0 \\
\hline & 사모펀드 전체 & 코스피200선물 & -0.0597 & -0.34 & 0 & 0 \\
\hline & 사모펀드 전체 & 아파트매매지수 & 0.1588 & $4.23^{* * *}$ & 8 & 8 \\
\hline & 사모펀드 전체 & 대체투자BM & -0.2099 & $-2.09^{* *}$ & 2 & 2 \\
\hline & 증권형 & 주식혼합BM & 0.2259 & $2.78^{* * *}$ & 1 & 3 \\
\hline & 채권형 & KIS종합채권 & 0.0715 & $4.57^{* * *}$ & 0 & 0 \\
\hline & 채권형 & 스프레드 & -1.4449 & $-4.98^{* * *}$ & 1 & 3 \\
\hline & 채권형 & 국채3년물 & -0.0292 & -1.65 & 1 & 1 \\
\hline \multirow{8}{*}{$\begin{array}{l}\text { 패널 } \mathrm{B}: \\
\text { 금융기관 }\end{array}$} & 사모펀드 전체 & 금융업 전체 & -0.1849 & -0.95 & 0 & 0 \\
\hline & 사모펀드 전체 & 은행 & -0.1712 & -0.68 & 0 & 0 \\
\hline & 사모펀드 전체 & 보험 & -0.0696 & -0.34 & 0 & 0 \\
\hline & 사모펀드 전체 & 기타금융 & 0.7782 & $2.82^{* * *}$ & 1 & 2 \\
\hline & 주식형 & 보험 & 0.5166 & $4.95^{* * *}$ & 0 & 0 \\
\hline & 채권형 & 금융업 전체 & 0.3867 & $2.67^{* * *}$ & 1 & 1 \\
\hline & 채권형 & 은행 & 0.5144 & $2.78^{* * *}$ & 1 & 1 \\
\hline & 채권형 & 보험 & 0.2898 & $2.05^{* *}$ & 1 & 1 \\
\hline \multirow{11}{*}{$\begin{array}{l}\text { 패널 } \mathrm{C}: \\
\text { 금융안정성 }\end{array}$} & 사모펀드 전체 & FSI & 0.1354 & 1.45 & 2 & 2 \\
\hline & 사모펀드 전체 & $\triangle \mathrm{FSI}$ & 2.4660 & 1.61 & 0 & 0 \\
\hline & 사모펀드 전체 & $\mathrm{JPoD}$ & 5.3952 & $2.48^{* *}$ & 0 & 1 \\
\hline & 사모펀드 전체 & $\triangle \mathrm{JPoD}$ & 0.6563 & 0.73 & 0 & 1 \\
\hline & 채권형 & FSI & -0.3400 & $-5.39^{* * *}$ & 1 & 1 \\
\hline & 채권형 & $\triangle \mathrm{FSI}$ & -2.6259 & $-2.81^{* * *}$ & 1 & 1 \\
\hline & 채권형 & JPoD & -2.3619 & $-4.25^{* * *}$ & 1 & 1 \\
\hline & 채권형 & $\triangle \mathrm{JPoD}$ & -1.6602 & $-2.61^{* *}$ & 1 & 1 \\
\hline & 부동산형 & $\triangle \mathrm{FSI}$ & 2.6782 & $2.67^{* * *}$ & 1 & 1 \\
\hline & 부동산형 & $\triangle \mathrm{JPoD}$ & 0.5198 & 0.98 & 0 & 1 \\
\hline & 특별자산형 & $\triangle \mathrm{FSI}$ & 5.6490 & $6.64^{* * *}$ & 3 & 4 \\
\hline
\end{tabular}

사모펀드 시장 확대가 금융안정성에 미치는 직접적인 영향은 <표 $6>$ 의 패널 $\mathrm{C}$ 에 정리되어 
The Effect of Private Fund Expansion on Financial Stability

있다. 사모펀드 시장 확대는 금융안정성에 제한적으로 부정적인 영향을 미치는 것으로 밝혀졌다.17) 사모펀드가 증가하면 $\mathrm{JPoD}$ 가 동차에서 증대되는 것으로 나타났다. $\mathrm{FSI}$ 나 $\mathrm{FSI}$ 증분, $\mathrm{JPOD}$ 증분도 모두 사모펀드 증가와 양의 관계를 보였으나 통계적으로 유의하지는 않았다. 유형별로는 금융안정성에 미치는 영향이 상반되게 나타났다. 채권형 펀드의 경우에는 규모 증대가 FSI나 $\mathrm{JPoD}, \mathrm{FSI}$ 및 $\mathrm{JPoD}$ 증가율에 대해 시차 1 에서 모두 통계적으로 유의한 음의 관계를 보여 채권형 사모펀드 증가가 오히려 금융안정성을 강화하는 것으로 밝혀졌다. 반면 부동산형이나 특별자산형의 경우에는 금융안정성을 저해하는 것으로 나타났다. 두 유형 모두 펀드 수탁고가 $\mathrm{FSI}$ 증분에 대해 양의 관계를 보였다. 반면 $\mathrm{JPOD}$ 에 대해서는 부동산형의 경우 양의 관계를 보였으나 통계적으로 유의하지 않았고 특별자산형의 경우에는 그랜저인과 관계 자체가 존재하지 않았다. 이 같이 사모펀드 유형별로 금융안정성에 미치는 영향이 상이한 이유는 결국 해당 사모펀드가 관련 시장에 대한 변동성을 확대시키기 때문으로 추론할 수 있다. 즉 적정규모 이상의 자금이 쏠림현상으로 인해 특정 자산에 몰리는 경우 해당 자산군의 가격변동성이 확대되어 변동성이 증가된다. 부동산형과 인프라나 실물자산에 투자하는 특별자산형의 경우 자산가치에 적합한 시장규모가 존재하는데 필요 이상의 자금이 몰리는 경우 해당 자산군의 변동성이 확대되면서 시장의 안정성을 저해할 수 있는 것이다. 금융안정성은 결국 변동성의 측정이라는 측면에서 볼 때 부동산형이나 특별자산형의 급격한 증가가 은행의 파산가능성을 기준으로 측정되는 $\mathrm{JPOD}$ 에 비해 경제지표의 변동성을 기준으로 측정되는 $\mathrm{FSI}$ 에 대해 훨씬 민감하게 반응한 것은 본 추론을 반증하는 결과라고 할 수 있다.

사모펀드 증가가 금융안정성 지표에 미치는 영향을 좀 더 정확하게 분석하기 위해 금융안정성 지표에 대한 분산분해를 실시했다. 분석결과 <그림 6>에서 보는 바와 같이 $\mathrm{FSI}(\mathrm{S} 1)$ 나 $\mathrm{JPOD}(\mathrm{S} 3)$ 모두 채권형이 지표에 미치는 영향이 가장 큰 것으로 나타났다. 3 기까지는 주식형(F3)과 채권형(F5)이 FSI나 JPoD에 미치는 영향이 유사하게 나타났지만 그 이후부터는 채권형이 주식형에 비해 월등히 미치는 영향이 컸다. 예컨대 채권형은 FSI 변동에 대해 6기부터 약 $30 \%$, $\mathrm{JPoD}$ 변동에 대해서는 약 $20 \%$ 정도 공헌을 하는 것으로 나타났다. 반면 $\mathrm{JPOD}$ 증가율(S4)에 대해서는 주식형이 채권형보다 더 많은 영향을 미쳤다. 한편 FSI 증가율(S2)에 대해서는 4기 이후부터 특별자산형(F9)의 역할이 지대한 것으로 나타나 주목할 만 했다.

17) 사모펀드 시장 확대가 금융안정성에 미치는 영향은 경로분석을 통해 보다 구체화할 수 있을 것이다. 예컨대 Schrimpf et al.(2020)는 저금리 기조로 인해 레버리지 투자를 많이 한 사모펀드가 코로나19로 인해 채권가격이 하락하자 채권을 강제매각(forced sell), 시장의 안정성을 악화시켰다고 지적하였다. 하지만 본 연구의 경우 표본기간 중 기준금리가 $2 \%$ 미만인 저금리 기간은 2015 년 이후로 제한적이었고 사모펀드의 레버리지 자료는 확보가 불가능해 이를 검증할 수 없었다. 이 밖에 다른 경로를 추정할 수 있겠으나 이는 방대한 추가분석을 필요로 하는 작업으로 향후 연구과제로 남겨둔다. 
〈그림 6> 유형별 사모펀드 증가율에 대한 금융안정성 지표의 분산분해
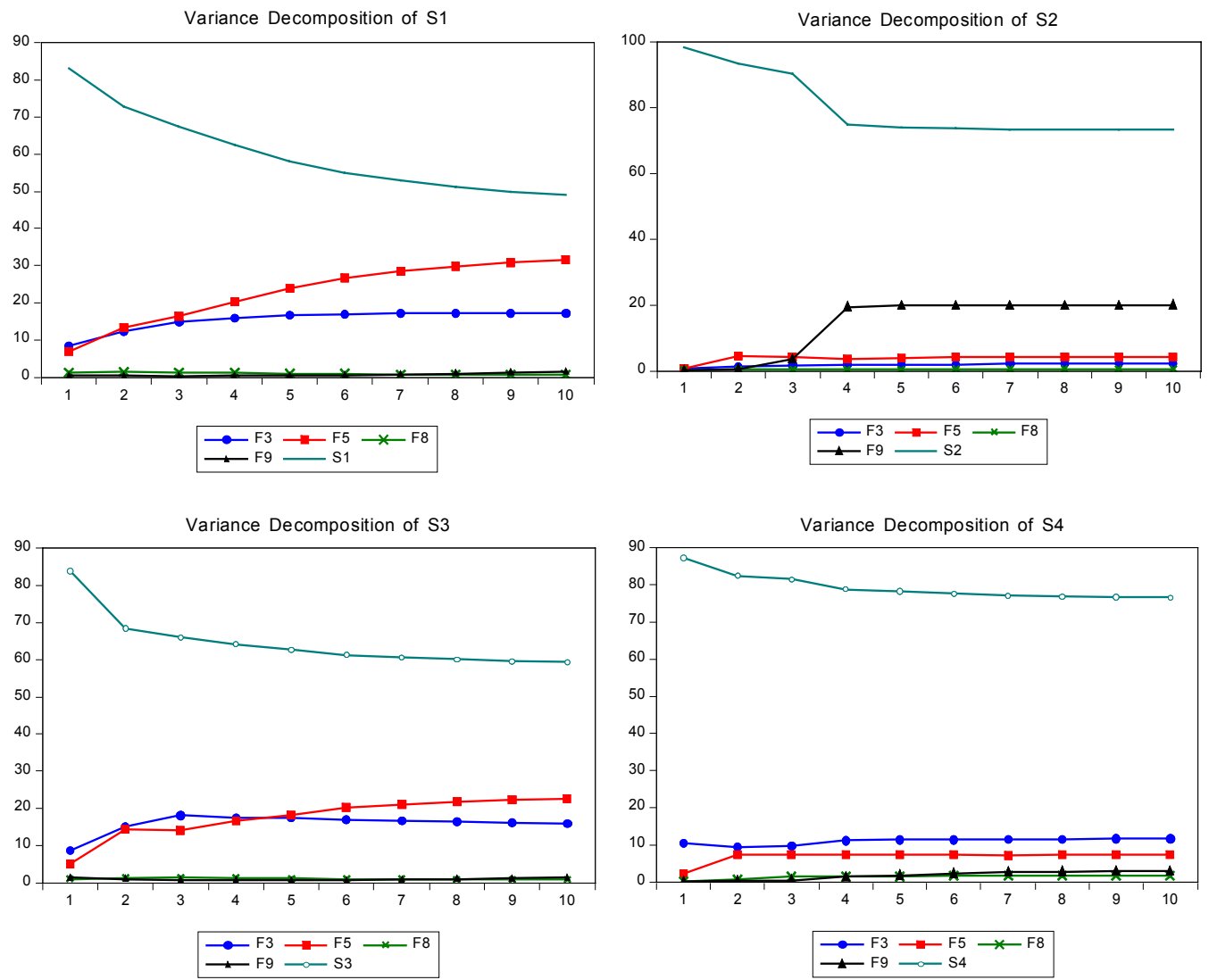

\section{4 금융업종별 투자펀드로의 자금유출입과 펀드의 자금흐름}

본 절에서는 금융업종별 투자펀드에 대한 자금유출입과 펀드 전체의 자금흐름간의 관계를 분석했다. 금융업종별 투자펀드에 대한 자금유출입은 일반은행, 특수은행, 신탁, 서민금융, 보험, 증권, 여신전문기관의 펀드에 대한 순자금유출액과 순자금유입액을 의미한다. 이 같은 금융업종별 투자펀드에 대한 자금유출입액은 한국은행에서 공시하는 분기별 자금순환표 상 투자펀드의 원천을 통해 추출할 수 있다. 다만 한국은행이 집계하는 펀드로의 투자금액은 전체펀드를 대상으로 하여 공모와 사모를 명확하게 구분할 수 없다는 한계점이 존재한다. 이에 따라 본 연구에서는 펀드의 자금흐름 측면에서 전체 펀드 뿐 아니라 공모와 사모펀드로 구분하여 금융업종별 투자 펀드에 대한 자금유출입과의 관계를 분석했다. 즉 금융업종별 투자펀드가 공모로 투자되었는지 사모로 투자되었는지 구분이 불가능한 상황에서 전체 펀드, 공모, 그리고 사모펀드의 자금흐름을 추출하여 금융업종별 전체투자펀드로의 이전금액과의 관계를 검증한 것이다.

금융업종별 투자펀드로의 자금유출입과 전체 펀드의 자금흐름 간에는 <표 $7>$ 에서 보는 바와 같이 선도 지연관계가 거의 존재하지 않는 것으로 밝혀졌다. 이는 금융기관들의 펀드 
The Effect of Private Fund Expansion on Financial Stability

〈표 7〉 금융업종별 투자펀드 운용을 위한 자금유출입과 펀드 자금흐름유출입간의 그랜저인과관계 ***, *** *는 각각 $1 \%, 5 \%, 10 \%$ 수준에서 유의성을 나타낸다.

\begin{tabular}{|c|c|c|c|c|c|}
\hline & 금융업종 & 1 & 2 & 3 & 4 \\
\hline \multirow{14}{*}{ 펀드전체 } & \multirow{2}{*}{ 일반은행 } & $6.40^{* *}$ & $5.04^{* *}$ & 1.53 & 0.64 \\
\hline & & 0.14 & 0.66 & 0.37 & 0.57 \\
\hline & \multirow{2}{*}{ 특수은행 } & 0.38 & 0.70 & 0.15 & 0.12 \\
\hline & & 0.01 & 0.04 & 0.19 & 0.66 \\
\hline & \multirow{2}{*}{ 신탁 } & 1.15 & 2.35 & 1.70 & 0.55 \\
\hline & & 0.55 & 1.25 & 0.96 & 0.91 \\
\hline & \multirow{2}{*}{ 서민금융 } & 0.07 & 1.28 & 1.23 & 2.02 \\
\hline & & 1.19 & 0.84 & 0.66 & 2.00 \\
\hline & \multirow{2}{*}{ 보험 } & 0.02 & 0.19 & 0.36 & 0.93 \\
\hline & & 0.04 & 0.25 & 0.55 & 0.59 \\
\hline & \multirow{2}{*}{ 증권 } & 0.30 & 0.20 & 1.16 & 0.82 \\
\hline & & 1.47 & 1.44 & 1.64 & 0.78 \\
\hline & \multirow{2}{*}{ 여신전문 } & 0.10 & 0.22 & 0.08 & 1.36 \\
\hline & & 0.72 & 1.55 & 1.17 & 0.76 \\
\hline \multirow{8}{*}{ 공모펀드 } & \multirow{2}{*}{ 일반은행 } & 2.58 & $3.25^{*}$ & 1.11 & 1.59 \\
\hline & & 1.86 & 0.40 & 0.25 & 1.53 \\
\hline & \multirow{2}{*}{ 특수은행 } & 0.11 & 0.34 & 0.13 & 0.28 \\
\hline & & 0.17 & 0.08 & 0.12 & 0.65 \\
\hline & \multirow{2}{*}{ 신탁 } & 2.09 & $3.18^{*}$ & $2.99^{*}$ & 1.31 \\
\hline & & 0.79 & 1.70 & $2.79^{*}$ & 1.92 \\
\hline & \multirow{2}{*}{$\rightarrow$ 서민금융 } & 0.33 & 0.46 & 0.57 & 0.62 \\
\hline & & 0.53 & 0.23 & 0.23 & 1.96 \\
\hline \multirow{6}{*}{ 공모펀드 } & \multirow{2}{*}{ 보험 } & 0.00 & 0.42 & 0.32 & 0.64 \\
\hline & & 0.48 & 0.40 & 0.50 & 0.46 \\
\hline & \multirow{2}{*}{ 증권 } & 0.89 & 0.13 & 0.93 & 0.65 \\
\hline & & 0.55 & 1.19 & 0.78 & 0.69 \\
\hline & \multirow{2}{*}{ 여신전문 } & 0.84 & 0.36 & 0.06 & 0.65 \\
\hline & & 0.00 & 0.83 & 0.46 & 0.35 \\
\hline \multirow{14}{*}{ 사모펀드 } & \multirow{2}{*}{ 일반은행 } & 0.00 & 0.40 & 0.55 & 0.45 \\
\hline & & 1.77 & 0.97 & $2.37^{*}$ & 1.52 \\
\hline & \multirow{2}{*}{ - 특수은행 } & 0.03 & 0.13 & 0.25 & 0.26 \\
\hline & & 0.81 & 0.27 & 0.78 & 0.98 \\
\hline & \multirow{2}{*}{$\rightarrow$ 신탁 } & 0.87 & 1.22 & $2.50^{*}$ & 1.43 \\
\hline & & 0.03 & 0.99 & $2.88^{*}$ & 2.11 \\
\hline & \multirow{2}{*}{$\rightarrow$ 서민금융 } & 0.79 & $3.70^{* *}$ & 2.07 & 1.86 \\
\hline & & 1.06 & 2.03 & $2.75^{*}$ & 1.85 \\
\hline & \multirow{2}{*}{ 보험 } & 0.68 & 0.80 & 0.60 & 0.56 \\
\hline & & 0.07 & 0.04 & 0.18 & 0.23 \\
\hline & \multirow{2}{*}{ 증권 } & 1.98 & 0.69 & 0.55 & 0.38 \\
\hline & & 0.85 & 1.32 & 0.69 & 0.24 \\
\hline & \multirow{2}{*}{ 여신전문 } & 1.19 & 1.16 & 1.02 & 0.85 \\
\hline & & $3.30^{*}$ & 1.18 & 2.25 & 1.56 \\
\hline
\end{tabular}


한국증권학회지 제49권 6호 (2020)

투자가 펀드의 자금흐름에는 별다른 영향을 미치는 않는다는 의미라고 할 수 있다. 자금흐름표 상의 투자펀드로의 자금유출입이 금융기관들의 실질적인 투자인지 해당 금융기관을 이용하는 개인이나 기관투자자들의 자금이전인지가 명확하지 않아 구체적인 관련성을 보이지 않는 것으로도 추론할 수 있다.

다만 선도 지연관계가 존재하는 경우 펀드 전체와 공모, 사모펀드 간에는 금융업종별 투자 펀드로의 자금유출입과 다소 상이한 방향의 인과관계를 도출했다. 즉 펀드 전체와 공모펀드는 금융업종별 자금유출입이 펀드의 자금흐름에 선행하는 반면 사모펀드의 경우에는 펀드의 자금흐름과 금융업종의 자금유출입간에 상호 그랜저인과관계가 존재하는 것으로 나타났다. 예컨대 펀드 전체의 경우 일반은행의 투자펀드로의 자금유출입이 펀드 전체의 자금흐름을 선도하고 공모펀드도 일반은행과 신탁의 펀드로의 자금유출입이 공모펀드의 자금흐름에 앞서 이루어지는 것으로 나타났다. 반면 사모펀드의 경우에는 펀드의 자금흐름과 신탁, 서민금융기관의 투자펀드로의 자금유출입이 상호 선도관계가 존재하는 것으로 나타났다. 특히 상호 선도관계의 경우 대부분 시차 3 에서 통계적으로 유의하게 나타나 금융기관의 펀드로의 자금유출입과 실제 펀드의 자금흐름간에는 일정기간이 소요되는 것을 알 수 있다.

금융업종별 투자펀드로의 자금유출입과 펀드의 자금흐름 간에는 별다른 관계가 존재하지 않는 것으로 나타났지만 만일 사모펀드가 실제로 부실화 되는 경우 펀드로 유입된 자금의 원천기관인 금융기관 입장에서는 신용위험이 증대될 수 있다. 따라서 금융업종별 펀드로의 자금유출입이 펀드전체, 공모, 사모펀드의 자금흐름에 영향을 미치는지를 역으로 살펴 보았다.

분석결과 <표 8>에서와 같이 사모펀드의 자금흐름에 보험사와 증권사, 여신전문기관의 펀드로의 자금유출입이 양의 관계를 갖는 것으로 밝혀졌다. 특히 은행의 펀드 투자액은 사모펀드 자금흐름에 별다른 영향을 미치지 않지만 보험사는 다른 금융업종에 비해 직접적인 영향을 미친다는 본 연구의 결과는 시사하는 바가 크다고 할 수 있다. 반면 공모펀드의 경우에는 일반은행과 서민금융기관, 증권사의 펀드투자액이 공모펀드의 자금흐름에 영향을 미치는 것으로 나타났다. 따라서 사모는 보험, 공모는 은행이나 증권사의 펀드로의 자금유출입이 펀드

〈표 8〉 금융기관의 투자펀드 운용 자금흐름이 펀드의 자금유출입에 미치는 영향 ***, ** *는 각각 $1 \%, 5 \%, 10 \%$ 수준에서 유의성을 나타낸다.

\begin{tabular}{|c|c|c|c|c|c|c|}
\hline & \multicolumn{2}{|c|}{ 펀드전체 } & \multicolumn{2}{|c|}{ 공모펀드 } & \multicolumn{2}{|c|}{ 사모펀드 } \\
\hline & 계수 & $\mathrm{t}$ 값 & 계수 & t값 & 계수 & $\mathrm{t}$ 값 \\
\hline 일반은행 & 0.2197 & $3.46^{* * *}$ & 2.1793 & $4.38^{* * * *}$ & 0.0889 & 0.22 \\
\hline 특수은행 & 0.2327 & 1.42 & 2.2212 & 1.63 & 0.1793 & 0.19 \\
\hline 신탁 & 0.2736 & 1.32 & 2.4366 & 1.41 & -0.0426 & -0.04 \\
\hline 서민금융기관 & 0.7522 & $1.96^{*}$ & 6.0442 & $1.87^{*}$ & 1.5553 & 0.71 \\
\hline 보험 & 0.1522 & $2.14^{* *}$ & 0.1367 & 0.22 & 0.9646 & $2.52^{* *}$ \\
\hline 증권 & 0.5643 & $4.14^{* * *}$ & 3.2670 & $2.55^{* *}$ & 1.6163 & $1.86^{*}$ \\
\hline 여신전문기관 & 0.7488 & 1.60 & 2.7676 & 0.68 & 5.0090 & $1.98^{*}$ \\
\hline
\end{tabular}


The Effect of Private Fund Expansion on Financial Stability

흐름과 더 관련성이 높다고 할 수 있다. 펀드 전체적으로 보았을 때는 일반은행과 서민금융기관, 보험사, 증권사에서 투자펀드로 이전된 자금이 펀드의 자금흐름에 통계적으로 유의한 양의 관계를 시현했다.

다음으로 펀드로의 이전자금에 대한 금융업종별 상호연관성을 분석하였다. 사모펀드가 부실화되는 경우 사모펀드에 투자한 금융기관들의 상호연관성 정도에 따라 체계적위험이 증폭될 수 있기 때문이다. 금융업종별 투자펀드 이전자금에 대한 그랜저인과관계를 분석한 결과 금융 업종간 투자펀드 이전자금에 대해 단 하나의 그랜저인과관계도 도출되지 않았다. 즉 투자펀드에 대한 자금이전은 금융업종별로 독립적으로 발생하고 있는 것으로 해석할 수 있다. 이에 따라 식 (5)에서 식 (8)을 이용한 금융업종 상호간 영향(out), 피영향(in), 통합(out+in)의 그랜저인과관계 정도(DGC)는 산출되지 못하였고 근접성(closeness)과 중심성(centrality)도 계산이 불가능하게 되었다. 이 같이 금융업종별로 펀드로의 투자시행을 독립적으로 시행하고 있는지에 대한 여부는 금융업종별 펀드로의 이전자금에 대한 상관관계를 분석한 결과 명확화 되었다. 분석결과 업종간 이전자금의 상관계수는 상당히 낮게 산출되었고 통계적으로 유의한 관계는 단 하나도 존재하지 않았다. 심지어 신탁과 보험 및 여신전문기관의 경우 투자펀드로의 자금유출입이 상호간에 역관계를 나타내기도 하였다.

〈표 9〉 금융업종별 투자펀드 자금유출입간의 상관계수

\begin{tabular}{lcrrrrrr}
\hline & 일반은행 & 특수은행 & 신탁 & $\begin{array}{c}\text { 서민 } \\
\text { 금융기관 }\end{array}$ & 보험 & 증권 & $\begin{array}{c}\text { 여신 } \\
\text { 전문기관 }\end{array}$ \\
\hline 일반은행 & 1 & & & & & & \\
특수은행 & 0.28 & 1 & & & & & \\
신탁 & 0.27 & 0.25 & 1 & & & & \\
서민금융기관 & 0.34 & 0.13 & 0.23 & 1 & & & \\
보험 & 0.07 & -0.36 & -0.08 & -0.15 & 1 & & \\
증권 & 0.05 & 0.00 & 0.00 & 0.12 & 0.31 & 1 & \\
여신전문기관 & 0.15 & -0.01 & -0.24 & -0.10 & 0.02 & -0.14 & 1 \\
\hline
\end{tabular}

\section{5. 결론 및 정책적 시사점}

\section{1 결론}

본 연구는 사모펀드 수탁고 증가가 금융안정성에 미치는 영향을 분석했다. 구체적으로 금융시장과 금융기관의 수익률에 미치는 영향을 살펴보았고 금융안정지표와의 관련성을 분석했다.

분석결과 사모펀드 시장의 확대는 전반적으로 금융시장에 부정적인 영향을 미치는 것으로 밝혀졌다. 사모펀드 증가는 KOSPI 지수 하락과 대체투자 벤치마크의 하락을 이끌어 주식시장과 대체투자시장의 수익률 악화에 기여했다. 또한 서울 아파트매매지수에 대해서는 8개월의 시차를 두고 매우 강한 정관계를 보여 부동산가격 상승에도 한 못을 담당하고 있는 것으로 드러났다. 
한국증권학회지 제49권 6호 (2020)

유형별로 구분하여 분석한 결과, 개별 유형들의 펀드 수탁고 증가율은 해당 시장의 수익률 하락에 직접적인 인과관계를 보이는 경우는 드물었다. 다만 채권형 사모펀드의 경우에는 $\mathrm{KIS}$ 종합채권지수 수익률과 양의 관계를 보여 오히려 시장안정에 공헌한 것으로 나타났다.

사모펀드 수탁고 증가와 금융기관 수익률간의 관련성 분석에서는 펀드 시장 확대가 금융기관 수익률에 대해 인과관계를 갖기보다 그 반대의 경우, 즉 금융기관 수익률이 펀드 시장 확대에 인과관계를 보이는 경우가 더 많았다. 특히 금융업종별로는 증권이나 보험사의 수익률이 펀드시장 확대를 선도하는 것으로 나타났다. 반면 은행의 경우에는 펀드 수탁고가 은행 수익률에 대해 인과관계를 보였고 기타금융의 수익률과 펀드 수탁고는 상호간에 관련성이 존재하는 것으로 나타났다. 펀드 수탁고 증가가 금융기관 수익률에 직접적으로 영향을 미치는지에 대한 분석 결과 사모펀드 증가는 은행이나 보험사의 수익률 하락을 가져오지만 통계적으로는 유의하지 않은 것으로 나타났다. 반면 유형별 분류 상 채권형 펀드의 경우에는 오히려 금융업 전체나 은행 보험사의 수익률 증대에 기여하는 것으로 밝혀졌다.

무엇보다도 사모펀드 증대는 금융안정성에 제한적이지만 부정적인 영향을 미치는 것으로 드러났다. 사모펀드 전체 증가율은 $\mathrm{FSI}$ 나 $\mathrm{JPOD}, \mathrm{FSI}$ 증가율, $\mathrm{JPOD}$ 증가율에 정관계를 보였고 특히 $\mathrm{JPOD}$ 증가에는 통계적으로 유의하게 기여하는 것으로 나타났다. 또한 유형별로 볼 때 부동산형과 특별자산형 증가는 FSI 증가율을 증폭시키는 것으로 밝혀졌다. 반면 채권형의 증가는 모든 금융안정성 지표의 하락을 이끌어 다른 유형과는 달리 금융안정성 유지에 오히려 도움이 되는 것으로 밝혀졌다. 또한 채권형 펀드는 금융안정성 지표의 분산분해 결과 다른 유형에 비해 지표에 미치는 영향이 큰 것으로 나타났다.

금융업종별 투자펀드에 대한 자금유출입은 사모펀드의 자금흐름과 별다른 관련성이 없는 것으로 밝혀졌다. 극히 일부의 금융업종이 펀드의 자금흐름과 인과관계가 존재함을 보였다. 다만 펀드 전체와 공모펀드의 경우에는 금융업종별 투자펀드로의 자금유출입이 펀드의 자금 흐름을 선도했다면 사모펀드에서는 펀드흐름이 금융업종별 펀드의 자금유출입을 이끄는 양상을 보였다. 펀드 부실 시 펀드로 유입된 자금의 신용위험 발생가능성을 검토하기 위해 시행한 금융업종별 펀드 투자가 펀드의 자금흐름에 미치는 영향에 대한 동차적 분석 결과 사모펀드의 경우 보험, 증권, 여신전문기관의 펀드 투자가 사모펀드 자금흐름에 영향을 미치는 것으로 밝혀졌다. 하지만 펀드로의 이전자금에 대한 금융업종별 상호연관성 분석에서는 업종간 단 하나의 관련성도 발견되지 않았다.

본 연구는 금융안정성에 미치는 사모펀드의 영향력을 분석했지만 사모펀드에 대한 충분한 자료확보가 불가능하여 정교한 분석이 이루어지지 못했다는 한계점을 지니고 있다. 즉 사모펀드는 금융당국에 수익률이나 운용규모 등을 제한적으로 보고하고 있고 해당 자료의 공시도 이루어지지 않고 있다. 개별 $\mathrm{PEF}$ 나 헤지펀드의 월별 수익률 자료나 시스템적 리스크의 매개역할을 하는 프라임브로커에 대한 자료도 현실적으로 확보 불가능하다. 또한 금융기관과 사모펀드 간의 자금흐름을 직접적으로 파악하지 못하였다. 자금흐름표상 금융기관의 투자펀드는 공사모를 모두 합한 것으로 사모, 공모, 펀드 전체 수탁고의 규모를 통해 사모펀드와의 관련성을 간접적으로 검증할 수 밖에 없었다. 투자펀드는 실질적으로 부도 발생 가능성이 없기 때문에 투자펀드의 
The Effect of Private Fund Expansion on Financial Stability

부실은 위탁자의 평가손실로 나타나는데 자금흐름표상 위탁자의 실체파악이 불가능한 것도 제약점이라고 할 수 있다. 이와 함께 금융안정과 관련해 시장리스크만 파악했을 뿐 유동성리스크와 신용리스크는 고려하지 않은 한계점도 존재한다.

\section{2 정책적 시사점}

본 연구결과는 최근 여러 가지 문제점을 드러낸 사모펀드 시장의 안정적 정착을 위한 정책방향 설정에 도움을 줄 것으로 기대해 시사하는 바가 크다고 할 수 있다.

일단 본 연구결과는 금융당국이 그동안 진행해 온 사모펀드 시장에 대한 규제완화 일변도 정책방향의 재고 필요성을 제기한다. 사모펀드 수탁고 증가가 제한적이기는 하지만 금융시스템의 안정을 일부 악화시키는 것으로 밝혀졌기 때문이다. 특히 은행의 도산가능성을 중심으로 산출된 시스템적 리스크인 $\mathrm{JPOD}$ 와 통계적으로 유의한 관계를 보였다는 점은 주목할 만하다고 할 수 있다. 또한 사모펀드 증가는 주식시장과 대체투자 시장의 수익률을 하락시키는 반면 부동산가격의 상승을 견인하여 자산시장의 가격 왜곡현상을 초래할 가능성도 제기했다. 금융당국도 최근 사모펀드 규제완화에 대해 속도 조절을 하고 있는 것으로 파악되고 있으나 좀 더 정교한 정책 마련이 필요할 것으로 보인다.

둘째, 사모펀드 유형별로 별도의 관리방식을 적용해야 할 것이다. 사모펀드 전체와 사모펀드 유형별로는 금융안정성에 미치는 영향이 다소 상이하게 도출되었기 때문이다. 예컨대 채권형 펀드의 경우에는 전체 사모펀드와는 달리 금융안정성지표를 낮추는데 기여, 안정성을 오히려 증대시키는 것으로 밝혀졌다. 또한 채권시장지수와 정관계를 보이면서 채권에 대한 투자수익률 상승도 이끌었고 금융업 전체나 은행, 보험의 수익률 향상에도 영향을 미친 것으로 나타났다. 따라서 금융안정성을 저해하는 환매에 대한 적절한 정책이 선행되는 조건으로 채권형 사모펀드에 대해서는 보다 많은 자율성을 부여해도 될 것으로 판단한다. 반면 부동산형과 특별자산형은 채권형과는 전혀 다른 양태를 보였다. 이들은 은행중심의 시스템적 리스크인 $\mathrm{JPOD}$ 가 아닌 거시경제 전반적인 상황을 반영하여 산출된 시스템적 리스크인 FSI에 훨씬 민감하게 영향을 미친 것으로 나타났다. 이들 펀드의 영향력이 은행 뿐아니라 금융기관이나 금융시장 전체에 미칠 수 있음을 의미한다. 즉 부동산형이나 특별자산형의 경우 자산가치에 적합한 시장규모가 존재하는데 필요 이상의 자금이 몰리는 경우 해당 자산군의 변동성이 확대되면서 다른 자산군으로 전이, 시장 전체의 안정성을 저해할 수 있는 것이다. 이에 따라 최근 급증세를 보이고 있는 부동산형과 특별자산형 펀드에 대해서는 해외부분이 상당 부분 차지하고 있기는 하지만 투자처 등 운용방식에 대한 별도의 모니터링을 실시할 필요가 있을 것으로 생각된다.

셋째, 금융업종별로 사모펀드로의 자금흐름에 대한 면밀한 경로추적이 필요하다. 연구결과 금융기관들의 투자펀드로의 자금유출입과 펀드의 자금흐름 간에는 대체적으로 높은 인과관계를 보이지는 않았지만 공모펀드에 비해 사모펀드의 자금유출입에 대해 인과관계를 보이는 금융업종이 더 많은 것으로 밝혀졌기 때문이다. 예컨대 신탁이나 서민금융의 경우 투자펀드 운용을 위한 자금유출입과 사모펀드 자금유출입간에 시차를 두고 상호 인과관계가 존재하는 것으로 나타났고 일반은행과 여신전문기관의 경우에는 사모펀드의 자금유출입이 이들 기관의 
한국증권학회지 제49권 6호 (2020)

투자펀드 운용을 위한 자금유출입을 견인하는 것으로 나타났다. 또한 보험, 증권, 여신전문기관의 경우 사모펀드의 자금유출입에 대해 동일한 시기에 영향을 미치는 것으로 나타났다. 즉 펀드가 부실화되는 경우 공모에 비해 사모로 인한 금융기관들의 피해가 더 커질 수 있는 것이다.

넷째, 운용사나 판매사 등 위탁자나 프라임브로커, 사무관리사, 수탁사 등 시장 참여자들의 시장규율 기능을 강화할 필요가 있다. 최근 발생한 사모펀드 사건 사고는 일부 운용사나 판매사의 일탈행위로 간주되기도 하지만, 이 같은 소소한 시장질서 교란행위도 시스템적 리스크로 전이되어 금융시장 전체의 안정성을 저해시킬 수 있기 때문이다. 사모펀드 제도개편을 통해 개인 전문 투자자에 대한 자격요건 명확화나 일반 적격투자자에 대한 보호책은 강구된 반면 운용사 설립 및 운영, 판매사 등 수탁자와 관련된 제도개선은 논의되지 않았다. 특히 공모펀드보다 규제정도가 훨씬 낮은 사모펀드를 활용한 규제차익을 얻기 위해 실질적으로는 공모펀드이지만 사모펀드의 외관을 갖추어 판매하는 펀드에 대한 강력한 제재의 필요성을 제기한다. 업무집행사원(GP)의 불법적 운용행위, 판매사의 명령 지시 요청에 의한 펀드 운용, $\mathrm{OEM}$ 및 시리즈 펀드 판매 등이 포함된다고 할 수 있다. 이 같이 펀드 운용에 있어 편법 불법을 자행하는 이유는 영세하고 소규모인 전문사모운용사의 난립 때문으로도 해석할 수 있다. 실제로 규제완화 후 전문사모 운용사는 2019년 말 기준 217 개로 증가한 반면 대부분의 펀드가 설정액 100 억원 미만의 소형펀드이고 전체 사모운용사 중 절반이상이 2019년 적자를 기록한 것으로 알려지고 있다.18 운용사가 많아지면서 사모펀드 운용 전략과 상품이 다양해진 긍정적인 측면이 있는 반면 펀드간 쏠림현상이 심화되고 소형펀드의 한계점을 극복하고자 레버리지를 통한 무리한 투자로 인해 운용사의 부실가능성이 증대되고 있는 점은 금융시장 안정 측면에서 주의 깊게 살펴보아야 할 대목이다. Garbaravicius and Dierick(2005)도 사모펀드가 체계적위험을 발생시키는 원천 중 하나가 레버리지를 통한 차입이라고 밝힌 바 있다. 또한 프라임브로커나 사무관리사, 수탁사의 책임도 강화되어야 한다. 프라임브로커는 신용대출, 증권대여, 기록보관, 실적보고, 위험관리 시스템, 자본중개 등의 주요 역할을 담당하고 있으며 사무관리, 수탁사는 실제로 운용지시를 실행함에 따라 운용사의 위법이나 부당행위에 대한 인지가 가능하다. 하지만 그동안 이들 기관들은 낮은 보수율로 인해 사모펀드 운용절차에 대해 기계적인 업무만을 수행했을 뿐이다. King and Maier(2009)는 헤지펀드에 대한 직접적인 규제책을 적용하지 못하는 현실에서 프라임 브로커를 통한 규제는 시스템적 리스크를 감소시킬 수 있다고 주장한 바 있다.

마지막으로 사모펀드 관련 자료의 투명한 공개가 절실하다. 전문투자형 사모펀드의 경우 펀드전체에 대한 설정, 운용, 판매와 관련된 자료는 금융투자협회에서 비교적 상세하게 제공하고 있다. 하지만 개별 펀드에 대한 정보는 찾아보기 어렵다. 또한 경영참여형 사모펀드의 경우 정보공개 수준은 더욱 낮다. 대형 $\mathrm{GP}$ 의 경우에는 1 년에 두 차례, 중소형 $\mathrm{GP}$ 의 경우에는 1 년에 한차례 금융감독원에 펀드개황이나 투자기업 투자형태를 보고하는 수준이다. 감독원에서는 분기말 $\mathrm{PEF}$ 현황을 집계하여 발표하고 있지만 펀드명이나 $\mathrm{GP}$, 약정액 등 기초적인 정보만을 공개하고 있다. 물론 사모펀드의 경우 자세한 정보 공개는 투자전략의 노출이라는 측면에서

18) 조선일보 ‘라임 사태 겪고도 사모펀드 운용사 되레 늘었다' 2020년 1월 31일자. 
The Effect of Private Fund Expansion on Financial Stability

보호되어야 할 사항이지만 역으로 투자자의 알 권리를 보호한다는 차원에서 보면 최소한의 정보 공개는 이루어져야 할 것으로 생각된다. 동일한 관점에서 한국은행의 자금순환표 상 투자펀드를 공모와 사모로 구분할 필요도 있다. 현재는 자금순환표 상 운용이나 원천측면에서 공, 사모를 통합하여 투자펀드 관점에서만 자료를 집계하고 있다. 사모펀드의 시장규모나 중요성이 커지고 있는 시점에서 공, 사모 구분을 통해 금융업종 간 보다 명확한 자금흐름 파악을 가능하게 해야 할 것이다.

사모펀드의 시장 확대로 인해 금융안정성이 저해되는 징후는 아직 뚜렷하게 나타나지 않고 있다. 하지만 최근 발생한 사건 사고로 사모펀드에 대한 신뢰도는 크게 저하되었다. 이 같은 사모펀드에 대한 신용하락은 공모펀드에 대한 무관심으로 확대되어 전체 펀드시장의 침체로 이어지고 있다. 이런 와중에 특별자산이나 부동산 등 일부 투자유형으로의 쏠림현상은 잠재적 위험요인을 증폭시킬 수 있다. 본 연구 결과를 바탕으로 도출된 사모펀드 규제완화의 속도조절, 사모펀드 유형별 대책마련, 운용사 및 판매사의 시장규율 강화, 프라임브로커에 대한 책임 강화 등을 통해 사모펀드 확대로 인한 금융안정성 저해 가능성을 선제적으로 차단, 성장과 침체의 기로에 서 있는 사모펀드 시장의 건전한 발전방향을 모색해야 할 시점이다. 
한국증권학회지 제49권 6호 (2020)

\section{References}

Baek, I., 2018, Current Status of the Domestic Repo Market and Tasks to Improve Market Stability, Capital Market Focus 2018-17, Korea Capital Market Institute.

Bank of Korea, 2012, Systemic Risk Assessment Model for Macroprudential Policy (SAMP), Financial Stability Report, pp. 145-153.

Billio, M., M. Getmansky, A. W. Lo, and L. Pelizzon, 2012, Econometric Measures of Connectedness and Systemic Risk in the Finance and Insurance Sectors, Journal of Financial Economics, Vol. 104, pp. 535-559.

Bisias, D., M. Flood, A. W. Lo, and S. Valavanis, 2012, A Survey of Systemic Risk Analytics, Working Paper, U.S. Department of the Treasury. https://papers.ssrn.com/sol3/papers.cf m?abstract_id=1983602.

Chan, N., M. Getmansky, S. M. Haas, and A. W. Lo, 2006, Do Hedge Funds Increase Systemic Risk?, Federal Reserve Bank of Atlanta, Economic Review Fourth Quarter.

ECB, 2008, Financial Stability Review, Dec. 2008. https://www.ecb.europa.eu/pub/pdf/fsr/finan cialstabilityreview200812en.pdf

Garbaravicius, T., and F. Dierick, 2005, Hedge Funds and Their Implications for Financial Stability, Occasional Paper Series no. 34, European Central Bank.

IMF, 2015, Global Financial Stability Report: Navigating Monetary Policy Challenges and Managing risks. Chapter 3. The Asset Management Industry and Financial Stability.

King, M. R., and P. Maier, 2009, Hedge Funds and Financial Stability: Regulating Prime Brokers will Mitigate Systemic Risks, Journal of Financial Stability, Vol. 5, pp. 283-297.

Lee, J., J. Ryu, and D. P. Tsomocos, 2012, Measures of Systemic Risk and Financial Fragility in Korea, Annals of Finance, Vol. 8, pp. 1-30.

Schrimpf, A., H. Shin, and V. Sushko, 2020, Leverage and Margin Spirals in Fixed Income Markets, BIS Bulletin No. 2, BIS.

Yi, J., 2015, Measuring Systemic Risk of Financial Institutions in Korea, Review of Financial Information Studies, Vol. 4 (1), pp. 1-26.

Yi, J., 2017a, Performance Analyses of Private Funds: From an Alternative Investment Perspective, Korean Journal of Financial Studies, Vol. 46 (1), pp. 187-216.

Yi, J., 2017b, Interconnectedness Among Financial Institutions Regarding Loan Behavior of Vulnerable Households and its Impact on Systemic Risk, Journal of Money \& Finance, Vol. 31 (3), pp. 127-166. 